\title{
The Mon Paradigm and the Evolution of the Pagán Temple
}

ONE OF THE most important assertions made by the Mon Paradigm, with a significant impact on the "knowledge" of the art and architecture of early Burma, concerned the evolution of the hollow Pagán temple called the $g u,{ }^{1}$ a most ubiquitous style found there. Invariably the issue of the solid stupa or cetiya (zedi in Burmese) gets entangled in the analysis of the gu, but it will be part of the discussion only in so far as it is pertinent to the evolution of the gu and the Mon Paradigm interpretation of it. The critical question is one of origins and development: when, in what form, and from where did the Pagán gu emerge, and how did it develop? Is it, as the Paradigm claims, a Mon inspiration?

Although I would have preferred to leave this task to an art historian, because the hidden assumptions of the Mon Paradigm are not always apparent to art historical issues, the art historian therefore may not have had the occasion to seriously consider the implications of that thesis. I feel the Paradigm assumptions with regard to this field of study should be exposed first, after which art historians can reassess the established view independently of the Mon Paradigm, something that has been done only cautiously or not well at all. ${ }^{2}$

The overriding assumption, and hence the analytical framework, of the Mon Paradigm is the familiar one: that Mon Lower Burma civilized Burman Upper Burma. In terms of religious architecture this meant that the Pagán temple is said to have evolved first through a "Mon phase," then a "transitional phase," and finally, a "Burmese phase." ${ }^{3}$ Not surprisingly the scheme resembles the Mon Paradigm's evolution of the writing system of Pagán, and like the other arguments, the development of temple style is used to support other Mon Paradigm claims. ${ }^{4}$

\section{The Present State of the Subject}

Whether one agrees with him or not, Luce's Old Burma-Early Pagán is the first important publication in English that attempted to provide a general 
theory regarding the evolution of the Pagán temple. As such, it is the starting point for any discussion of Pagán's “art historiography.” It is also important for its factual data, which remain some of the most solid, detailed, and reliable, produced by one of the foremost scholars of Pagán. In recent years, however, a far more comprehensive, thorough, and neutral work on the architectural history of Pagán has appeared. This is Pierre Pichard's Inventory of Monuments at Pagán, published in seven volumes with an eighth that has just come out. ${ }^{5}$ In cooperation with international and national organizations and individuals, Pichard has spent about a quarter of a century at Pagán on this work.

The Inventory focuses on the physical remains of largely religious buildings that were built on the approximately sixteen square miles of Pagán. The volumes are organized geographically, with every monument catalogued, numbered, measured, and provided with coordinates. Among other useful data, there are ground plans, cross sections, construction material, size, estimated date of construction, relevant and clear photographs, and a very helpful system of cross referencing throughout the corpus. It is, in my opinion, the most important compendium of architectural information on the archaeological site of Pagán published so far. The seven volumes I have seen include 2,064 monuments, more than three-quarters of which belong to the period between the eleventh and fourteenth centuries. Of these, approximately 810 are hollow temples or $g u{ }^{6}$

Using more or less the same organizational scheme and covering part of the same ground as Pichard is the first volume of Myanmar Ministry of Culture's publication in Burmese called Inventory of Ancient Monuments. ${ }^{7}$ This is a catalogue 150 buildings, based (as Pichard's complication is) on their geographic location (in this case around Nyaung-U), rather than on any predetermined, stylistic chronology. It includes the inventory number of each temple, ground plan, cross section, name of donor (when known), date or period to which each might belong (if known), basic measurements, and usually a color photograph of each edifice.

There were earlier works produced on Pagán, ${ }^{8}$ most notably Henry Yule's, ${ }^{9}$ which made important contributions to the study of its architecture, particularly some remarkable cross-sectional drawings of select Pagán temples. Yet such studies also imposed Eurocentric impressions consistent with the times, as we see here articulated by Mr. Oldham, a member of Yule's expedition.

So strongly unlike all other Burman buildings, can these have owed their origin to the skill of a Western Christian or Missionary? . . May not the true crosslike plan of the Ananda be thus symbolical, and may he not, in the long-trusting hope of a zealous worshipper of Christ, have looked forward to the time 
when this noble pile might be turned from the worship of an unknown god to the service of the Most High? I can't think any Burman ever designed or planned such buildings. . . .10

Of this Yule admitted, "such an impression, I know, was almost irresistible at times when on the spot. But, ... I cannot think it [sic] probably founded in truth." 11

In the early twentieth century, scholars like Taw Sein Ko and Duroiselle, both of whom worked for the Archaeological Survey, did much of the earliest spade work. They were followed by numerous scholars belonging to various disciplines, although none that I know of were art historians at the time. Art history was, at least in the field of Southeast Asia, a relatively new discipline. The late U Bo Kay, longtime resident and unassuming director of archaeology at Pagán, produced one of the first books in Burmese that systematically analyzed most of the important temples at Pagán, following a chronology based on early Burmese texts. ${ }^{12}$ These were meticulous records of works of merit, mainly of royalty and the elite. And since building a religious edifice was probably the most important event in anyone's life in Burmese Buddhist society, these carefully preserved records are likely to be fairly reliable as sources. As director of archaeology, U Bo Kay had access to stone inscriptions as well, which he could use to cross check the texts. Unlike Luce, U Bo Kay avoided presenting any kind of broad conceptualization of temple styles or Pagán's art history. U Aung Kyaing, one of U Bo Kay's successors, who until recently held the same post of director of archaeology at Pagán, has been instrumental in maintaining the explosion of excavations and repairs and the building of a large, new museum. ${ }^{13}$ His book, also in Burmese, ${ }^{14}$ is even less concerned with the broader perspective of Pagán temple evolution and takes a much closer look at artistic details of select temples. It is rarely cited as a source in the works of current western art historians because few read Burmese well enough to make any credible assessment of it. Others, such as $\mathrm{U}$ Ba Shin, have focused on a single temple, while historian Than Tun has provided important insights into art history with his scholarship on epigraphy and history.

Among western aficionados of Pagán art, Paul Strachan's Kiscadale Press has provided valuable support for Pichard's Inventory. Although paying great deference to Luce, Strachan's own work has managed to wriggle free of the Mon Paradigm to a certain extent, even though it is still chained to it in many regards. ${ }^{15}$ For the most part, however, his Pagan may be one of the first among western art books in English to criticize, albeit very gently and sparingly, some of the sacrosanctity of Luce's Old Burma-Early Pagán. ${ }^{16}$ At the same time, Strachan's work is based less on rigorous scholarship than on personal experience and knowledge of popular culture, so 
his book is more a "coffee-table" treatment of the Pagán temples than a scholarly treatise. There are other art historians of Burma whom I have not discussed here, not because their works are unimportant, but mainly because they have focused on specialized subjects such as painting ${ }^{17}$ or different regions of Burma, such as Arakan, ${ }^{18}$ and do not directly address the issues being pursued here. ${ }^{19}$

It was Luce more than anyone else who formulated a thesis on the evolution of the Pagán temple, so it is his work that receives the closest scrutiny. This focus on Luce, as in the other chapters, is not meant to disparage him as a scholar of Pagán, but to reexamine the viability of his ideas, particularly his interpretation of the facts. For the most part, the facts themselves are not in dispute. But because Luce's "fingerprints" are all over Pagán studies, it is impossible not to mention his work every time an issue dealing with Pagán is raised.

Luce divided the evolution of the Pagán temple (both zedi and gu) into four periods or phases associated with the reigns of several notable kings. There was the pre-Aniruddha period, the reign of Aniruddha (1044-1077), the reigns of Saw Lu, Kyanzittha, and part of Alaungsithu's (1075-1105), and the "transitional period" (1113-1174). The first, he wrote, was a "period of widespread Paganism" and "peaceful co-existence between Buddhism and Vaishnavism . . . a common feature ... ." at Pagán. The second period, he claimed, saw the ascendancy of Buddhism, but in the absence of canonical texts (obtained only after the alleged conquest of Thatôn), it was "thinly spread" and therefore in balance between the Mahāyāna of East Bengal and Arakan and the Theravāda of Dvāravatī and Old Prome. Luce saw strong Pyū influence in architecture but "after the capture of Thatôn, Mon beauty of colour, ornament and design combines with Pāla Bengal strength to produce the typical art-forms of Early Pagán.” The third period, he argued, followed the arrival of the full Tipitakas from Śri Lanka around 1075. It was characterized by the expansion of Theravāda Buddhism and the "splendid series . . . of 'Mon' temples. . . . The first masterpiece is Păhtothămyā, the climax Nanda temple...." The last phase "witnessed the gradual passage from Old Mon dominance to Old Burmese. The first flowering is at Shwégugyi,... the first masterpiece Thatbyinnyu temple...." ${ }^{20}$ Because his Old Burma-Early Pagán does not go beyond 1165 and the alleged "capture of Pagán by Parākramabāhu's armada" - a thesis already demonstrated to be entirely without merit ${ }^{21}$ - the work ends in the mid-twelfth century. Thus although the period to which he technically confines his evolutionary scheme begins with the "pre-Aniruddha period" and ends with King Kalagya, its implications go well beyond that date and also beyond mere chronology.

A second idea that shaped Luce's perspective on the evolution of the 
Pagán temple was his belief that the hollow temple evolved from the solid stupa. ${ }^{22}$ As he envisioned it, the temple began with the stupa, which was "essentially circular. ... The big change comes with the squaring of the circle: not by tampering with its shape, but by building it up from below, placing the square under it, usually with an octagon in between. The lotus mat on which the cetiya rests ... remains circular and topmost; but as the squareness below grows larger, the circle above gets less [sic]. The square terrace invited decoration: in Aniruddha's pagodas, usually Jātaka plaques, lining the plinth in pockets, . . . but 550 pockets were too many for the single terrace, and the unglazed plaques needed protection: so he added a low vaulted corridor, where the whole series could be fitted on both sides. ..."23 The vaulted corridors then became the roofs, so that interior space was created. And thus we have the evolution of the hollow Pagán temple directly from the solid stupa, a thesis that is highly problematic.

The third and last factor that Luce believed shaped the evolution of the Pagán temple, particularly in terms of a specific style, had to do with the temperament of certain ethnic groups. As he put it, "the Mon, like the Indian, is more of an Introvert"; ${ }^{24}$ that "taste for dim religious light... owed more, I suspect, to the romantic and poetic temperament of Old Mons, ... [whereas] the Old Burman, a more earthy and prosaic person, as soon as he began to control the building, cleared the perforated windows, drove out the bats, opened large doorways on each face, and placed the main Shrine high above him on a platform. ..." 25

Luce elaborated by explaining what he meant by a Mon as opposed to a Burman temple. A Mon temple was "normally one storey, and in plan apparently asymmetric. It consists . . of a square main block, the temple proper, containing a central Shrine or recess for images; a half-arched corridor (or corridors) surrounding it; and a vaulted Hall (with the only means of entrance) on one side. The main block is always dark, for the windows ... are of perforated stone or brick. Even the Corridor is dim; and the Shrine containing the colossal image would often be pitch-dark, if it were not for... skylights casting mysterious rays on the face of the Buddha. Such temples, if not ruined, have nearly always Old Mon writing, never Old Burmese." ${ }^{26}$ As we shall see, this elaboration was a self-fulfilling attempt that, wittingly or not, nevertheless reinforced the Mon Paradigm.

\section{Problems of ANALYSIS}

Luce's four-phase evolutionary scheme poses some problems. Using the reigns of kings to organize historical periods in art implies that the pace and path of temple evolution is the same as that for political history, and the criterion and factors responsible for the evolution of temple style in Pagán is closely related to the personal reigns of kings and their particular histor- 
ical circumstances. Yet the evidence shows that the stylistic development of the Pagán temple followed its own tempo and course, determined more by its own criteria-such as architectural and engineering concerns, the wealth accumulated by individuals and the state, occasionally personal preferences, and sometimes by the introduction of new or different religious ideasthan by political succession.

Luce's methodology also implies that the development of temple type was more an issue of time, for he adopted a standard western linear approach in which a direct cause-and-effect relationship existed between the passage of time, change, and progress, ${ }^{27}$ thereby linking time with type as an irrevocable part of temple development.

Yet there was astounding continuity of the most dominant styles (or types), which suggests that "change" and "progress" in temple architecture were not inevitable consequences of the mere passage of time, even long periods of it. Rather, the evolutionary process not only at Pagán but in Burma in general is best represented by what the late Stephen J. Gould called in paleontological theory "punctuated equilibrium," where long periods of equilibrium-such as, in our case, the Pyū millennium-are punctuated by short periods of dramatic change-such as twelfth- and early thirteenth-century Pagán.

Indeed, the most dominant styles continued unchanged fundamentally; many temples built in the thirteenth century ${ }^{28}$ retained all or most of their basic "prototype" forms without necessarily producing new "species." The Pagán temple did not evolve along an inevitable linear path from A to $\mathrm{B}$, from prototype to its assumed offspring. Instead, many late temples remained very much like their earliest prototypes, retaining their original shapes, sizes, and designs, a pattern we shall examine in detail below.

Another problem with Luce's analysis is that he selected only 55 temples out of the 2,170 known at the time to represent his four-phase evolutionary scheme. ${ }^{29}$ Of those 55 , only 8 are securely dated by their own inscriptions, and 4 of them Luce rejected because they did not fit his criteria. ${ }^{30}$ That means only 4 temples out of his chosen 55 (about 7 percent) have confirmed, epigraphic dates. Indeed, the original, epigraphic records of nearly 97 percent of the temples thought to be built during the Pagán period are missing, ${ }^{31}$ so that their chronology is open to debate.

The reader may be surprised to learn, for example, that neither the famous Ānanda Temple attributed to King Kyanzittha nor the Shwéhsandaw attributed to Aniruddha has an original inscription that identifies the donor and date of construction; nor, for that matter, does the Shwézigôn, which is attributed to both. That attribution, though long thought to be true (and very possibly true), is nevertheless conjecture. Even the Thatbyinnyu, which has an in situ Pali inscription, does not explicitly say that it was 
Alaungsithu who built it, even though it has long been attributed to him. In some cases a reasonable argument can be made that a certain temple belongs to a particular king's reign, usually because of identifiable votive tablets found inside or similar data, but even then the identity of the actual donor would still be uncertain.

Thus most of our current knowledge regarding donors and dates of Pagán temples is only accepted convention based on later texts and lists. But without these, there would hardly be a chronology of Pagán temples today, much like Burmese history itself. ${ }^{32}$ These records include poems that celebrate the building of a temple, donative records kept on palm leaf, thamaing (histories) of specific temples, royal chronicles, and the stone and ink inscriptions found in the temples themselves.

Even if all the fifty-five temples selected by Luce were securely dated, the sample is too small to represent an evolutionary scheme for the entire Pagán period which stretched over several centuries and may have once included over 3,000 edifices. ${ }^{33}$ It is true that Luce ended his study at 1165 $\mathrm{AD}$, but he did so because from then on he considered most, if not all, temples to be "Burman" in style. In effect, he was dealing with the entire Pagán period.

In the absence of original epigraphy to confirm the chronology of temples, especially Luce's selected fifty-five, perhaps he should have taken a detailed look at style, other written texts that provide dates, construction methods, materials used, and, if financially feasible, scientific testing as a way of estimating the period to which the temples may have "belonged." Instead, Luce's selection was predetermined by the Aniruddha conquest story and his alleged acquisition of Theravāda Buddhist texts from Thatôn and Śrī Lan̉ka. Luce's choice, ultimately, was made under the assumption that an earlier Mon civilization existed in Lower Burma that had provided the necessary artistic and architectural models.

Let me cite just two specific examples. The dating of the Păhtothămyā temple ${ }^{34}$ was determined by the historicity of the conquest of Thatôn story. This disallowed its being any earlier than Aniruddha's reign because the paintings found in the temple were said to have been based on texts belonging to the Sinhalese Tipitakas, and the Mon Paradigm could not concede that these texts existed in Pagán before Aniruddha's alleged raid of Thatôn. ${ }^{35}$ And with no conquest of Thatôn, the mechanism for the importation of Śri Lan̉kan Buddhism to Pagán would have also been removed, thereby contradicting virtually every interpretation of Pagán's history, art history, and culture. Indeed, an entire generation of scholarship would have had to be reworked. However, if the temple were dated later than Aniruddha's reign - which is what Luce $\operatorname{did}^{36}$ — then the Mon Paradigm would be upheld once more, and even "reconfirmed." 
The other temple is the Lokahteikpan. U Ba Shin, whose contribution to the study of Pagán, particularly his seminal work on this temple is well recognized, and which Luce endorsed, ${ }^{37}$ wrote that "no written evidence, inscriptional or otherwise, regarding its donor or its date has yet been discovered. ..." The style of the Lokahteikpan, he continued, "differs from that of the typical 'Old Mon' type of temple, nor is it like that of the . . Burmese type of temple." ${ }^{88}$ The only indigenous alternative left, at least the most logical one to me, is that this was an earlier, Pyū-style temple. Indeed, Ba Shin himself admits that such "cave-temples" as the Lokahteikpan were first built by the Pyū, using the Léymyethna and the Bèbè of Śrī Kṣetra as models. "These two types of vaulted chapel[s] of the Pyūs," he wrote, "are probably the predecessors of the early gus or temples of Pagán." 39

Why, then, not take the next logical step and suggest that the Lokahteikpan and other similar temples, being closer to Pyū-period styles, must be earlier rather than later, especially since Ba Shin and other Pagán scholars knew (or at least believed) that the Burmans were the immediate successors of the Pyū? But that could not be, for inside the temple were archaic Burmese ink inscriptions, and if dated to a period earlier than King Kyanzittha's reign, when the first evidence of Old Mon appears, that would have placed the temple, and the Burmese writing system, earlier than the Mon writing system, which the Paradigm could not allow. The sacrosanct belief that things perceived to be Burman must be later than things perceived to be Mon, even when the evidence points in the opposite direction, would not allow such an option.

Ba Shin went on to say that "the Old Burmese writing of this temple is archaic - and its juxtaposition with Old Mon shows that the temple is clearly of the "transitional period," comparable in date with the so called 'Myazedi' inscription, which, with the Kubyaukgyi Temple of Myinkaba village ... dates from the very beginning of Alaungsithu's reign, say 1113 A.D." ${ }^{40}$ Dating this temple according to a predetermined chronology-in which Old Mon predates Archaic Burmese, in which a "transitional period" bridges the "Mon" and "Burmese periods," and in which the Myazedi Inscriptions are used to establish the earliest date for written Burmese rather than the established stylistic methodologies of art historians-is yet another exercise in circular reasoning. ${ }^{41} \mathrm{Ba}$ Shin conveniently placed the Lokahteikpan temple in the early twelfth century by declaring that the Archaic Burmese in it was later than Kyanzittha's Mon inscriptions. All of this corroborated the erroneous linguistic and historical arguments of the Mon Paradigm, rather than providing a reliable art historical basis for dating the Lokahteikpan.

The second criterion Luce used to delineate the evolution of the Pagán temple-that the hollow temple evolved from the solid stupa-is very puz- 
zling. Even undergraduate students of Asian art history would know better. Both the stupa and temple existed independently of each other in India as well as in Burma, at Pagán as well as at Śrī Kṣetra. They are a parallel, not a sequential development. A cursory glance at any art history text on the development of the stupa and temple in India would have dispelled this notion that temples evolved from stupas. ${ }^{42}$

However, if by his statement Luce meant that at Pagán components of the temple and stupa were combined, then that poses no problems. Many of the temples in Pagán were, in fact, a synthesis of temple and stupa elements, where a miniaturized version of the bell-shaped stupa (or a variation of it, such as the sikhara) adorned the hollow temple underneath. It is true that art historians of Pagán such as Strachan might appear to agree with Luce's thesis, ${ }^{43}$ but probably only in so far as the combination of elements in specific temples such as the East and West Hpetleik or Myinpyagu are concerned. Surely Strachan would not agree with the notion of a general evolution from the solid stupa to the hollow gu. These are clearly two different issues and historical processes.

Luce himself admitted that the "vaulted chapels of Śrì Kșetra . . . are clear prototypes of Pagán architecture: the Bèbè . . . the Lémyet-hna . . . [and] the East Zegu, ..." ${ }_{44}$ while in the case of the stupa, he wrote that "it is as if the Burmans saw and copied a Pyū ruin." ${ }^{45}$ This is, in fact, a recognition of parallel development of gu and stupa, so that Luce has contradictory theses being presented simultaneously, something that I cannot clarify for him. Figure 5 shows how the stupa evolved in Burma from the basic bulbous styles of the Pyū in the seventh and eighth centuries to those of tenth-century Pagán. From there (see Figure 6), it became a more distinctive form, with multiple plinths, during the Pagan period, until it arrived at today's highly elongated anda (literally "egg") as can be seen in the Shwédagôn at Yangôn. No stupa "became" a hollow temple.

The third and most serious problem in Luce's schema is the causal relationship he asserts between ethnicity and temple style, and style and chronology. ${ }^{46}$ By interjecting a category of style called "Mon temples," he introduces the totally unprovable, even if relevant, factor of ethnicity into a historical analysis of art. He ascribed the genesis of this "Mon style" temple to the supposed arrival of the "full Tipitakas" from Śri Lanka and the resulting "expansion of Theravāda Buddhism." This, he claimed, inspired the crafting of the "full" 550 Jätaka plaques that were then placed on the sides of the plinths of two stupas, the East and West Hpetleik, which he assigned to Aniruddha's reign. ${ }^{47}$ For the protection of these plaques, he noted, roofs in the form of vaults were created, thereby producing hollow gus. Luce's evolution of the gu from the stupa was now completely entangled with the creation of a vague new category called the "Mon temple." 

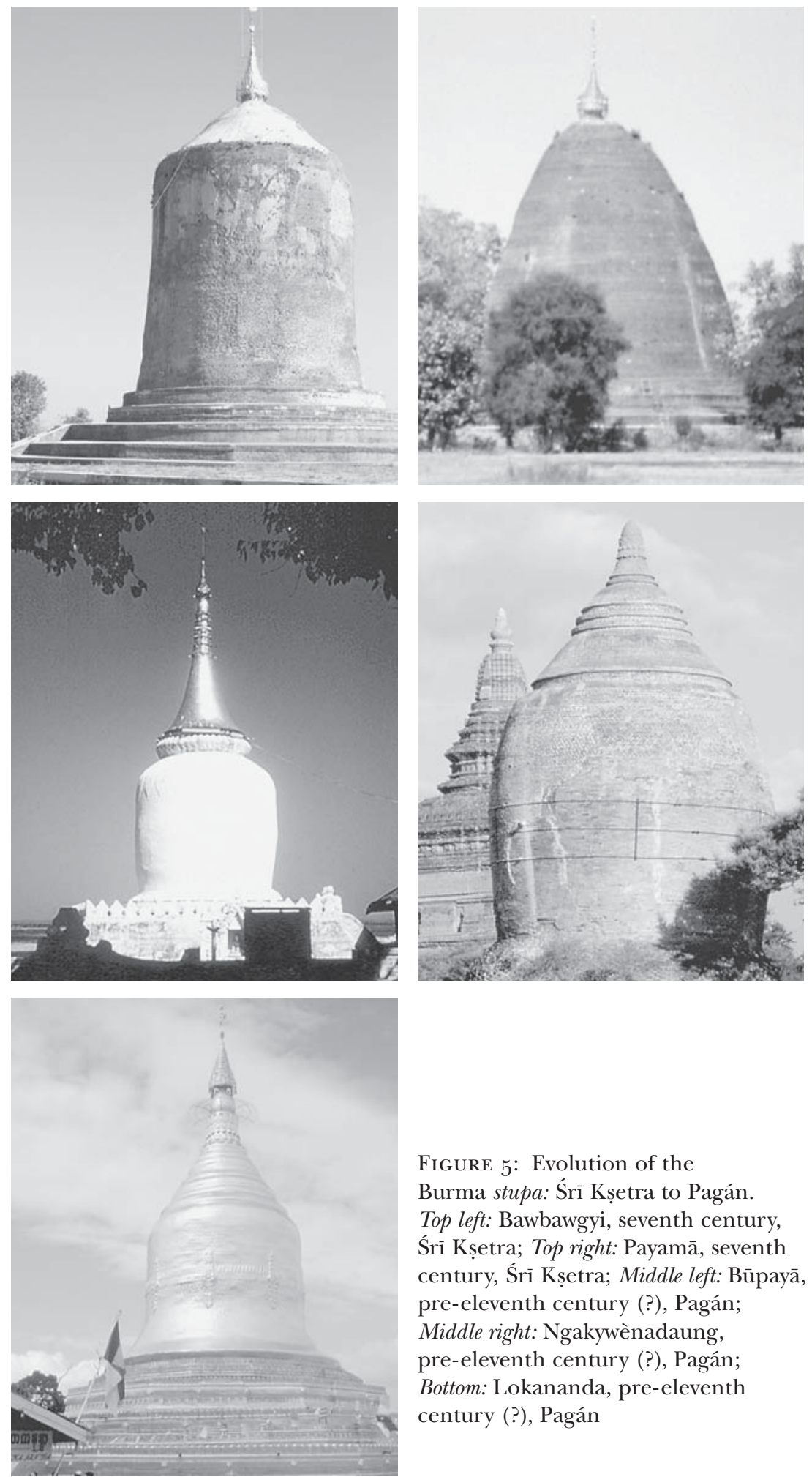

Figure 5: Evolution of the

Burma stupa: Śī Kṣetra to Pagán.

Top left: Bawbawgyi, seventh century, Śrī Kṣetra; Top right: Payamā, seventh century, Śrī Kṣetra; Middle left: Būpayā, pre-eleventh century (?), Pagán;

Middle right: Ngakywènadaung, pre-eleventh century (?), Pagán; Bottom: Lokananda, pre-eleventh century (?), Pagán 
Again, this approach did not examine the evolution of temple style in terms of art history, but according to factors relating to the Mon Paradigm views on the historicity of particular cultures, events, and kings.

Luce then went a step farther. As already noted above, he defined the structure of a Mon-style temple as being one-storied, asymmetrical, with a main square block and central shrine or recess for images, a half-arched corridor (or corridors) surrounding it, a dark vaulted hall with perforated windows, and the presence of Mon writing. But the design he describes in fact delineates one of two actual (Śrī Kṣetra) prototypes, the basic structure from which most hollow temples of Pagán are, in fact, derived. By labeling the prototype of the most prevalent style of gu at Pagán "Mon," of course "Mon temples" will precede everything else! And since his evolutionary scheme had predetermined that Mon temples preceded Burman ones, Burman temples would now also come after Mon temples.

Then in direct contradiction to his own criterion of Mon temples being asymmetrical, the exemplary model he provided for his Mon-style temple was the Ānanda, ${ }^{48}$ which is celebrated for its perfect symmetry, not asymmetry. He went on to explain that the essential reason he designated these prototype temples "Mon" was the presence in them of written Mon, usually in the form of ink inscriptions. Yet many of these Mon inscriptions, such as those in the Lokahteikpan, are much later additions, some as late as the seventeenth century, and therefore have nothing to do with the particular style of temple or its process of evolution, especially in the Pagán period, even if the ethnic argument were valid. Besides, there were many temples built in Pagán with the same or similar style that had no writing in them; what do we call these? In short, the reasons Luce gave for identifying these kinds of temples as "Mon" are spurious, selective, and contradictory.

After creating this elaborate if not confusing scheme, Luce finally added a disclaimer; saying that his use of the word "Mon" to describe these prototype temples was merely a matter of convenience..$^{49}$ But that convenient label had the effect of creating an inevitable link between ethnicity and style in the evolution of the Pagán temple that helped perpetuate the Mon Paradigm in the analysis of Pagán architecture for decades more to come.

The terms "Gothic" and "Baroque" serve as useful categories to identify certain European art styles, irrespective of the languages found within their contexts, the presence of such styles during the reigns of particular kings, or the ethnolinguistic group that created the artifacts. Italians as well as French and English, individuals as well as the state, could produce and recognize either style even if they changed them subtly. Why was it not possible to utilize a stylistic category derived from indigenous Burmese art vocabulary, rather than selecting an ethnic designation that did nothing to clarify or identify the artistic style one was attempting to describe? The rea- 

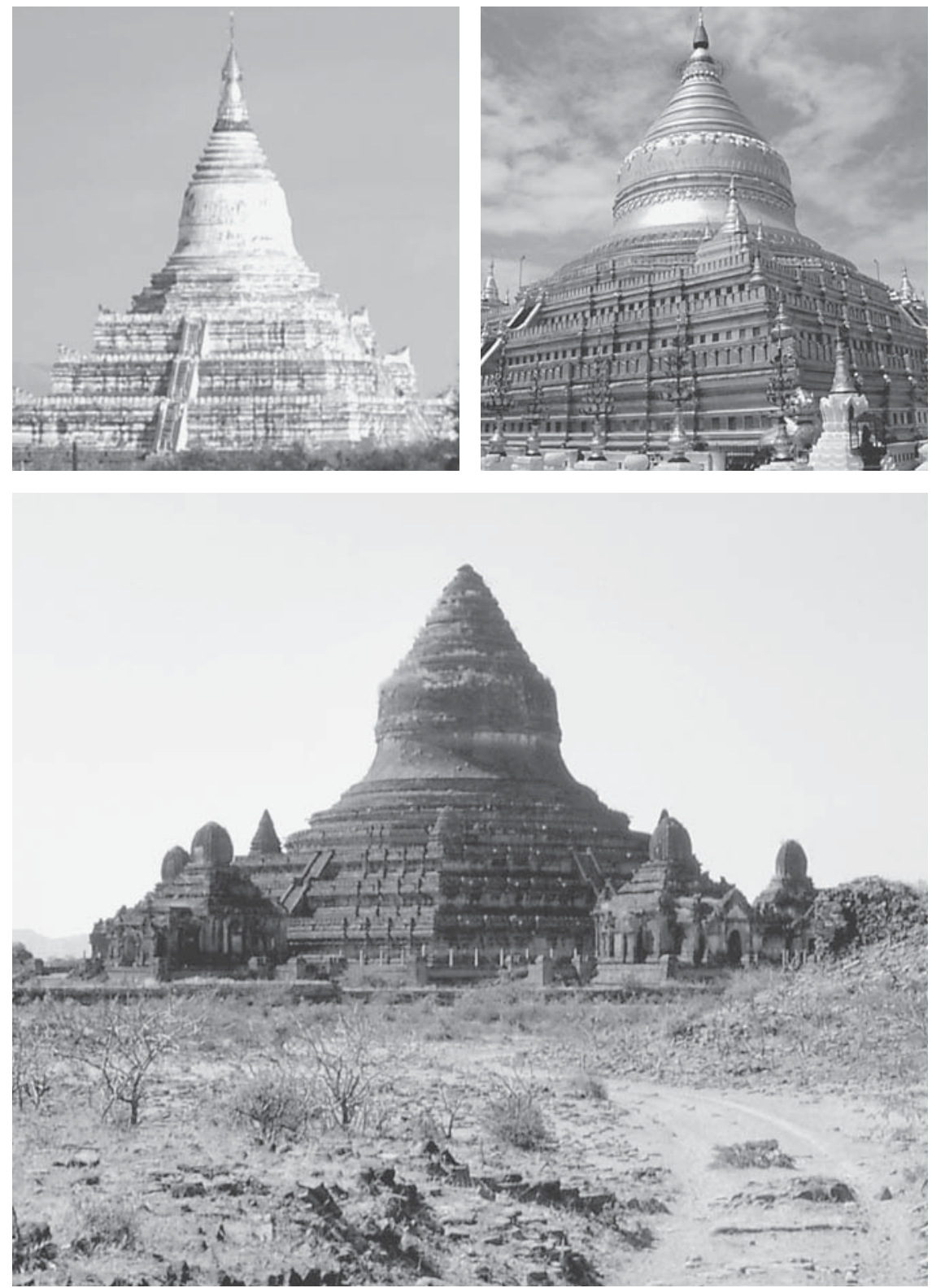

Figure 6: Evolution of the Burma stupa: Pagán to Yangôn.

Top left: Shwéhsandaw, eleventh century; Top right: Shwézigôn, eleventh century; Bottom: Dhammayazika, twelfth century.

Opposite page, Top: Mingalazedi, thirteenth century; Middle left: Htupayôn, midfifteenth century, Sagaing; Bottom left: Shwémawdaw, fifteenth century, Pegu; Right: Shwédagôn, fifteenth century, Yangôn 

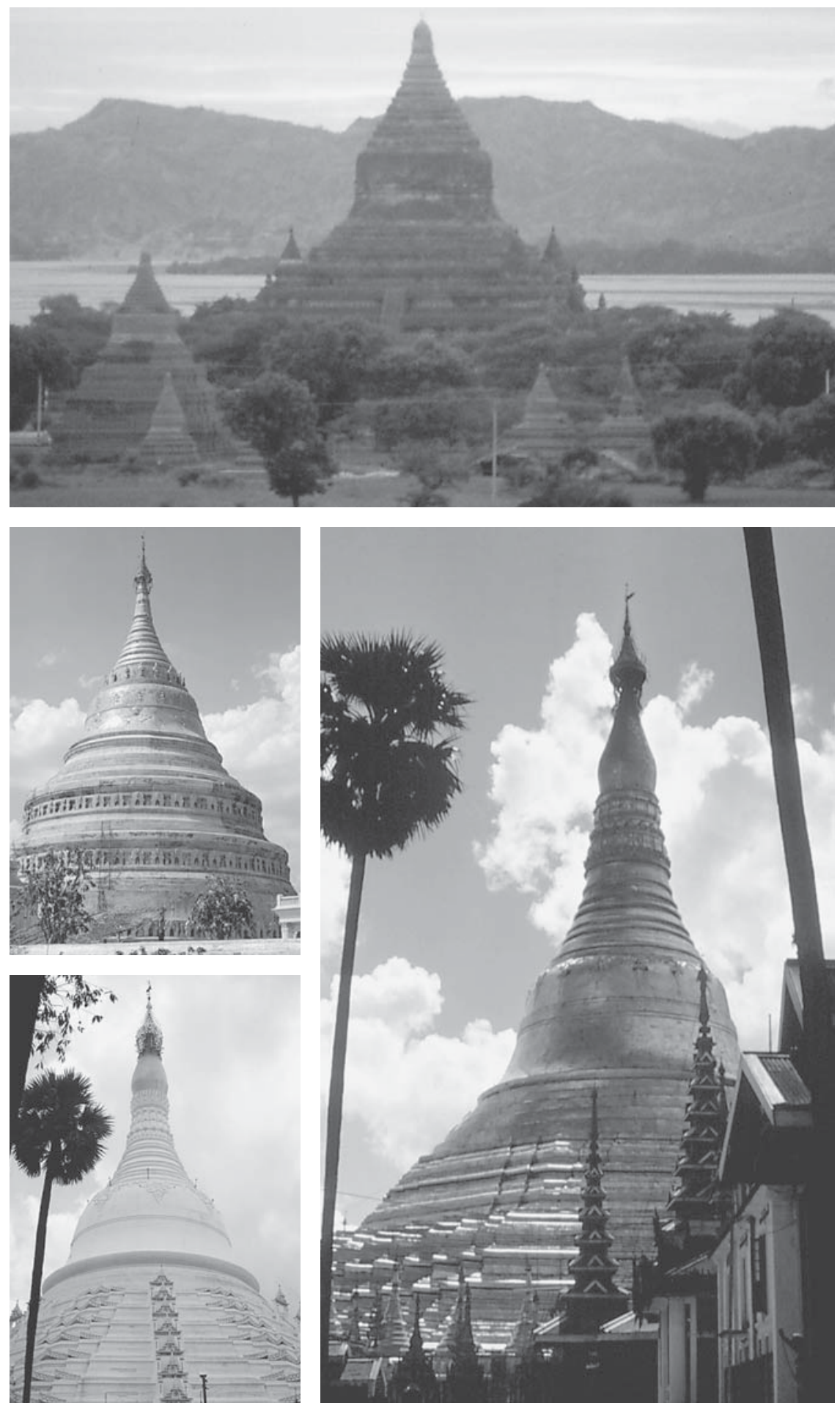
son, I am convinced, was an overall desire to enhance the causal role of Mon civilization in the making of Pagán, the heart of the Mon Paradigm. In terms of temple architecture, this translated into using the ethnic term mon to represent a style that turns out to be, conveniently, the basic Pyū prototype.

Most unprovable of the criteria Luce used is the attribution of general human personality characteristics, such as introspection and prosaicness, to a particular ethnic group because of its ethnicity. Even more untenable is to then use such personality traits as a causal factor in the development of a particular temple style, so that Mons who were supposedly introspective were said to have built edifices that are dark and confining, while Burmans who were characterized as prosaic built ones that were "light and airy." 50 Automatically, then, dark and confining temples such as the Ânanda, said by the chronicles to have been built by King Kyanzittha, were defined as Mon (even though it was perfectly symmetrical). And temples such as the light and airy Thatbyinnyu were considered representative of Burman style, even though the temple was said to have been built by King Alaungsithu, Kyanzittha's own grandson, and has an in situ Pali inscription, which according to Luce's own criteria should be classified as North Indian. And what ethnic designation should be given to the Shwézigôn and Mingalazedi? They are neither gloomy nor airy, since they are solid stupas with no interior space. Does that imply that neither Mon nor Burman built them? What happens if Tamil, Telegu, or Bengali craftsmen, confessed introverts as well as extraverts, built a temple in Pagán following a current and fashionable design? What ethnic designation would that temple have, and where in the four-phase evolutionary pattern would it fit stylistically?

And even if such essentialization of ethnicity, used as a causal factor in the development of style were accepted as a legitimate basis for argument, it still cannot explain the building of "gloomy" temples, such as the midtwelfth-century Dhammayangyi or the thirteenth-century Payathonzu and Nandamanya, along with many others like them, throughout the so-called "transitional (i.e. Burman) period" and later, when they were supposed to have been "light and airy." And what about temples like the so-called Manuha, attributed to the eleventh century and an alleged Mon king, which is not all that "gloomy" nor early? 51

Because a contrived relationship had been created between ethnicity and style and style and chronology, the Mon Paradigm was also compelled to attribute certain styles to certain prescribed "ethnic periods," even when many temples built at any one time were quite different stylistically and structurally, or, conversely, many were rather similar but built centuries apart. ${ }^{52}$ The possibility that different donors might have expressed personal preferences in selecting styles, or that building hollow temples with 
interior space was far more complicated, and therefore more expensive, than building solid stupas, or that a temple's size was directly related to socioeconomic and political stature (not to mention engineering principles) were issues never considered seriously. Social, economic, and political factors, even personal tastes were ruled out, and ethnicity became the most important criterion for determining the categorization and evolution of temple styles at Pagán. But that proclivity to reify ethnicity was a marked feature of the colonial, not the Pagán period.

This twentieth-century projection backwards of what were alleged to have been Mon and Burman temperaments assumed to have been derived from ethnicity, probably stemmed from the sentiments of the age as well as Luce's own personal experiences with both ethnic groups (he was married to a Mon lady and his brother-in-law was the noted scholar of Pali and Burmese literature, Pe Maung Tin). It is perhaps the most problematic, even if one attributes it, charitably, to poetic license.

Apart from such mentalities of the age or personal experiences which affected his interpretation, Luce-and others who followed in his footsteps -were also self-taught art historians. They may not even have been aware of the conceptual issues and problems that were being discussed in the theoretical literature of the discipline that helps inform one in the analysis of data. A similar problem existed in the broader field of Burma Studies, which was also, by and large, unaccountable to scholars outside it. While foreign scholars may have ignored or been unaware of works published in Burmese such as U Bo Kay's, at the same time Burmese scholars did not seriously consider, if they were even aware of, progress being made in the relatively young discipline of art history outside Burma.

\section{Problems OF Evidence}

Issues of evidence are, of course, closely intertwined with problems of analysis, and given that the primary weakness of the Mon Paradigm analysis of Pagán temple evolution rests with its treatment of evidence, it seems desirable to address that issue also.

\section{Thatôn as Prototype?}

The Mon Paradigm asserted that an earlier Mon civilization in Lower Burma brought about the later development of Pagán's architecture, despite the fact that, as an eminent archaeologist noted with some surprise, “... at Thatôn, not a single example of early temple architecture [of Burma] is to be found. ..." ${ }^{53}$ The belief regarding the antiquity of a Mon civilization in Lower Burma was so ingrained in the Mon Paradigm that the absence of evidence supporting that belief was more a cause for surprise than for questioning the assumption. 
Another example of "evidence" used by the Mon Paradigm to demonstrate early Mon influence in Pagán art are the Jātaka plaques on many stupas and temples, sometimes appearing as glazed terracotta reliefs outside these buildings. Luce answers his own question regarding the source for the Jattaka plaques on the Hpetleik pagodas by attributing them to Aniruddha, saying: "It is seen in embryo in the Shwéhsandaw plaques at Pagán Museum ... and is generally supposed (I think rightly) to have come with coastal Mon artists, after the capture of Thatôn." ${ }^{44}$ Yet the most important part of that assertion-the evidence for it in coastal Thatôn itself at the time-was not provided.

As a result of Luce's assertions, however, the few remaining terracotta plaques illustrating Jātaka stories that line the Myatheindan Pagoda located outside the city walls of Thatôn were conveniently "assigned to the 11th and 12th centuries." ${ }^{55}$ Why the eleventh and twelfth centuries? No explanation was given, except that the author apparently shared the Mon Paradigm view of Thatôn's earlier existence and the historicity of the Aniruddha conquest, so these plaques must have been earlier ${ }^{56}$ and must have been the source for Pagán's Jātaka plaques. But in fact, neither the Thagya-paya nor the Shwézayan Pagodas at present-day Thatôn, on which a few plaques of these kinds appear, have been dated. The plaques could just as easily (and more likely) have come from Pagán. Similarly, although the terracotta panels found at the village of Kyôntu, near Pegu, are, according to another art historian, "reminiscent of the terra cottas and the bronze dancing figures at Srisketra," they are nevertheless given a Mon provenance and placed in the subsection of his work entitled "The Mons of Suvannabhumi." ${ }^{57}$

If one removes the assumptions about an earlier Thatôn-as has been shown again and again in this book-the entire Mon Paradigm falls apart. In India the Jātaka stories appear on stone relatively early (second century BC onwards), so that there is no reason why this artistic influence, like many other cultural items, could not have also come directly from India, or through a local intermediary like the Pyū, well before the first proven Burman-Mon contact in the late eleventh century.

The green glaze on many Jätaka plaques could easily have been another Pyū contribution, for the walls of one of its major cities were said by a ninth-century Chinese source to have used "green bricks." ${ }^{58}$ In addition, one of the earliest bulbous stupas of Pagán, the Ngakywènadaung, was once covered with green glaze, parts of it still visible today. ${ }^{59}$ (See Figure 5.) Although green glaze and Jätaka plaques are not necessarily connected, the plaques are most often found with green glaze on them, and both usages precede the first appearance of the Mon in Upper Burma.

As other examples, when seven undated Old Mon inscriptions were found within the Shwézayan Pagoda at Thatôn, five were summarily attrib- 
uted to the eleventh century (the catch-all period), one to the "medieval period," while the last is illegible. A standing Buddha was also found which, unsurprisingly, was labeled a "prototype" of those in the Ānanda temple and conveniently dated to the tenth and eleventh centuries to precede them, ${ }^{60}$ while Brahmanic and Indic sculptures found at Thatôn were not only provided a similar antiquity but also a Mon provenance.

With no solid evidence, only vague, incontestable, and also unprovable, statements remain to demonstrate Mon influence in Pagán art. To reiterate, Luce wrote that “. . . after the capture of Thatôn, Mon beauty of colour, ornament and design combines with Pāla Bengal strength to produce the typical art-forms of Early Pagán." ${ }^{61}$ The statement implies that no "beauty of color" or "strength" (of what, we are not told), existed in Pagán art prior to the alleged conquest. That Mon "beauty of colour" and Bengali "strength" were ethnic traits, is, of course, impossible to affirm or deny, but became, nevertheless, part of the corpus of "evidence" for the Mon Paradigm.

It mattered little that no art and architectural remains even close to those left at Pagán in proven antiquity, quantity, and quality have been found at Thatôn. Even if the site is accepted as the Thatôn of legend and history for the sake of argument, it is barely 1,500 yards square, with at most three major stupas and about seven undated Old and Middle Mon inscriptions. ${ }^{62}$ This minuscule site was made to preempt Pagán, with its 2,800 monuments and nearly 1,200 surviving and mostly dated inscriptions, all produced several hundred years before Thatôn's first appearance in original epigraphy. And this is not to mention recent radiocarbon dates that show urban settlement at Pagán as early as the seventh century and the building of its palace by the tenth. Simply because Thatôn was assumed to have preceded Pagán, all remains of art and architecture found there and in Lower Burma in general were automatically considered to have been earlier, and made part of a scenario in which Pagán must have borrowed from Thatôn. The art of early Burma has not been analyzed independently of the Mon Paradigm, and it desperately needs to be.

\section{The True Arch and the Mon}

One of the most important and distinctive engineering features found in virtually all hollow temples of Pagán—the confident and ubiquitous use of the vault, which expressed knowledge of the true arch principle-points neither to Thatôn nor to the Mon in Burma or anywhere else. ${ }^{63}$ The architects of Pagán used the cloistered vault, the barrel vault, the cupola, the $3 / 4$ barrel, the 1/2 barrel, and the diaphragm vault. ${ }^{64}$ (See Figure 7 for a good representative of this arching principle.) And whereas its use was dominant and pervasive at Pagán, it is not found at all in Thatôn or anywhere else in 
Lower Burma, ${ }^{65}$ or, for that matter, at Dvāravatī or any other Mon site in Southeast Asia. ${ }^{66}$

Leaving aside the controversial issue regarding the origins of the Pagán arch, ${ }^{67}$ its absence in Lower Burma was attributed to the weather. As Luce put it: ". . . in view of the difference in yearly rainfall between Prome [this is equally applicable to Pagán as both lie in the Dry Zone] and the coast... may it not be an accident that vaulted temples survive at Prome [and Pagán] and not at Thatôn?" 68 In addition to explaining from the absence rather than the presence of evidence, Luce added that the Mon also rather "distrusted" the arch. ${ }^{69}$ No reason, certainly no evidence, was given for this alleged distrust. It was clearly an attempt to explain why no evidence of the arch existed among the Mon.

Besides, Luce's argument would imply that all 1,501 religious edifices built at Pagán that used the vault were not built by the Mon, since, after all, they distrusted it, including what Luce considered the quintessential Mon temple, the Ānanda. He had contradicted virtually everything he had said previously with that assertion. The statement was also disingenuous, for by saying that the Mon distrusted the arch, he implied that they actually knew the engineering principle but consciously chose not to use it, as if that somehow ameliorated the absence of the true arch among the Mon.

In fact, having knowledge of this engineering principle is very important, for its use directly affects the style of the gu: its shape, size, interior

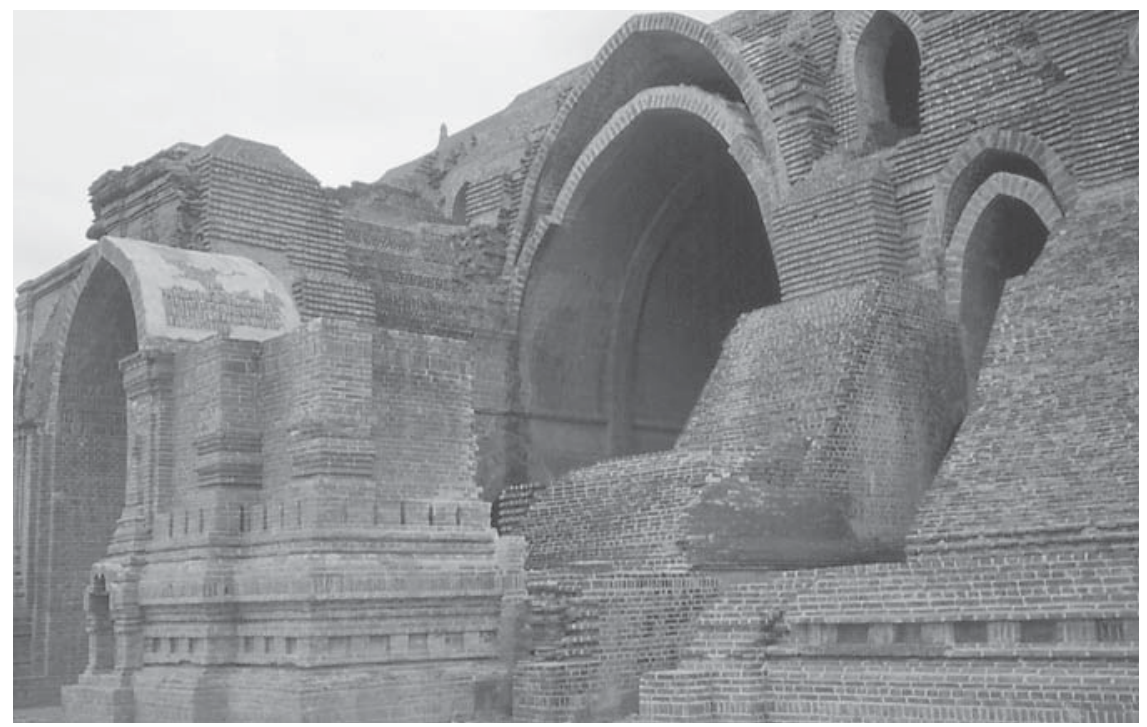

Figure 7: Pagán Arches 
space, thickness of walls, weight of roofs, size of superstructures, number of windows, and the number of storeys. It is directly related to the structure of the hollow temple and is an indispensable component of its design, whether symmetrical or asymmetrical, dark or airy, with Mon, Burmese, or no writing in it, so that one could say with aplomb that without the knowledge and use of this principle, the styles of the hollow temples of Pagán would not have been what they were. And since there is no evidence of this engineering technique or the style of $g u$ it invariably produced at any Mon site in Southeast Asia-Dvāravatī, Haripuñjaya, or Lower Burma-how can so structurally vital an engineering principle used in so prominent and ubiquitous a style at Pagán, be attributed to the Mon?

Although it has not been unequivocally established that the vaults in the seventh or eighth-century Bèbè, Lémyethna, and East Zegu of Śrī Kṣetra were original to the construction and not the result of later repairs by Pagán architects, ${ }^{70}$ the point is that the principle of the true arch and its use in a variety of vaulting techniques during the Pagán period and earlier are found exclusively in Upper Burma. And if the traditional dating of the Păhtothămyā to the tenth century, and the Lokahteikpan to a time before the Myazedi Inscriptions are accepted as valid, then developed vaulting existed, at least at Pagán, well before evidence of first Burman-Mon contact and the documented presence of the Mon in Upper Burma by 1102.

\section{The Vocabulary of Architecture and the Mon}

Other details important to the vocabulary of temple construction are also pre- or non-Mon (or put in a nonethnic way, pre or non-Rāmaññadesa). Inside some of these smaller temples, for example, can be found paintings the themes of which are taken mainly from Indic cosmology. Many depict Jätaka stories along with well-known figures found in Brahmanic and Buddhist literature. The 108 auspicious signs on the sacred footprints of the Buddha are represented often. The many (particularly the 28) Buddhas of the previous dispensations are regularly painted on the walls, with the historical Buddha, Gotama, most prevalent. Buddhist texts, such as the rules contained in the Vinaya are also represented in graphic form. It is apparent that the Dipavamsa or the Mahãvamsa were already known by the time of the Myinkaba Kubyaukgyi temple, the date of which is not certain, but in which can be found representations of certain important topics contained in those chronicles: the three Buddhist councils, the life of Aśoka, the coming of the religion to Śrì Lan̉ka, and even King Vijayabāhu, who in the myth and legend of Burma was an ally and friend of Aniruddha. ${ }^{71}$ At Pagán, then, although the precise date of arrival is unknown, these Śrì Lan்kan texts were probably already known and likely preceded the first original references in Lower Burma by nearly five hundred years, for there 
they are found first in Dhammazedi's Kalyani Inscriptions of the late fifteenth century.

The word for hollow temples in Old Burmese is written as $k u$ (pronounced $g u$ ), apparently taken from the Sanskrit guha ("cave") which both the Pyū (as go) and Mon (as guoh) were said to have adopted as well. ${ }^{72}$ The term (put'uiw, păhto) is also said to be Old Burmese and is used for the smaller hollow temples; the term is not, apparently, found in Old Mon. ${ }^{73}$ The word is said to have come from the Pali vatthu (ground, site). ${ }^{74}$ And as the gu or put'uiw was built at Śrì Kṣetra centuries before the first evidence of its presence at Pagán, and since it was found at Śrī Kṣetra well before the first documented appearance of the Lower Burma Mon there, it is likely that both the word and what it represents came via the Pyū. Here again, Luce admitted that "the large Pagán $k u$, 'temple,' evolved naturally from the vaulted chapels of Śrī Kṣetra." 75

The word for the metal finial is at'wat (crown) a Tibeto-Burman term, ${ }^{76}$ not an Austro-Asiatic one, the language family to which Mon belongs. The Burmese $h t i$ (Old Burmese $t^{\prime} \bar{\imath}$ ), now used generally for the metal finial, apparently comes from the Sanskrit (yaști, Pali yațhi), and was once a reference to the "umbrella pole" that held the at'wat. The anda, the "egg" which forms the bulbous cylinder of the stupa, goes back to at least the Sanchi dome in India. It was lengthened by the Pyū of Śrī Kṣetra in the Payagyi, Payamā, and Bawbawgyi stupas. As for the Pagán anda, one of the earliest is represented by the Būpaya, which, according to Luce, may "even go back to pre-Burmese times." 77 (See Figure 5.)

Many other words dealing with religious and related buildings owe nothing to the Mon language. One style of temple, called uman, comes from the Pali for "cave" (ummangga), and is most notably represented by the Kyaukku Ônhmin, an early cave temple dug into a hillside near Nyaung-U that may precede Aniruddha's reign. The Pali for tower, prāsāda (Burmese pyathat) is another term for the superstructure of the Pagán temple. The terms for the various parts of hollow temples, from the massive brick walls (tantuin) that surround them to the plinth (caikram) on which they stand, very likely derive from Sanskrit and then Old Burmese, not Old Mon. The word for ordination hall is also taken from the Pali sima $\bar{a}$, Old Burmese sim. The word for image (pum) comes from the Pyū bo. ${ }^{78}$ The word for library (cātuik) is Old Burmese, as is the word for preaching hall (trya im). Monastery is Old Burmese klon, a term later used for all schools, which had previously been called ca saituik. Buildings with a special roof normally built outside a monastery are still called (tanchoin). Rest houses (carap) were built as part of merit-making, meant for the use of pilgrims and others. Many practical nonreligious items were constructed to go along with religious donations, such as tanks or reservoirs (kan), wells (riy twain), causeways (tan- 
thah), bronze bells (kriy khorilori). None of these owe anything to the Mon language. They are either Pali, Sanskrit, or Old Burmese, and the earliest appearance of these terms in original epigraphy are found not in Lower but in Upper Burma.

The earliest structures in Lower Burma appear to have been built mainly with laterite, while brick was the preferred material and used almost exclusively in Upper Burma in all the Pyū sites and Pagán. This is not to say that building material is an ethnic issue; rather, it has to do with geography-what is an easily obtainable natural resource-and the culture of technology. Laterite is abundant in the Chao Phya basin and southeastern Lower Burma, so it is well known and used, but it is not found in Upper or Central Burma. In Burma's history, the earliest use of well-burnt brick belongs to the Pyū and Burman, not the Mon; to put it in a nonethnic, geohistorical context, brick use belongs to early Śrī Kṣetra and Pagán, not to later Rāmaññadesa.

Accordingly, the Old Burmese word for brick, $u t$, is said to have been derived from the Pali itthaka. ${ }^{79}$ Ut-phuiw (brick kiln) is also Old Burmese, and Luce makes no mention of any Mon equivalent. The word for stucco (arkatiy), often plastered on the brick at Pagán, is also said to be Indic and is mentioned as early as $1198 .{ }^{80} \mathrm{It}$ is the same word in Mon (ainkade), but is first mentioned in original epigraphy only in the late fifteenth century in Middle, not Old Mon, about three centuries after appearing in Old Burmese. ${ }^{81}$ This is not to suggest that Lower Burma did not have stucco until that time, but only that since the word and its use were much earlier in Upper Burma, the Burmese probably did not borrow it from the Mon.

Luce also declared that the Burmese word for mortar (sarwat) comes from Mon, but no evidence is provided except a citation to an inscription of $1236 \mathrm{AD}{ }^{82}$ Upon rereading the inscription, I found it has nothing to say about the etymology of sarwat, but just gives the cost of the mortar incurred in building an edifice. ${ }^{83}$ Besides, I find it unconvincing that the two cultures that used brick earliest and almost exclusively in Burma-the Pyū and the Burman-had to borrow the word for mortar from a culture that originally did not, and whose contributions to brick monuments at Pagán was either nonexistent or late and minimal. Finally, the distinctive "fingermarked bricks," uncovered in many Pyū sites as well as in Pagán, have also been found in Lower Burma, as noted in Chapter Two, well before the first Mon kingdom appeared in the late thirteenth century.

The suffix added to the names of crafts to identify various skilled craftspeople who had a direct hand in building Pagán temples ( $s a m \bar{a}$ "skilled person") is said to have been Mon in origin. ${ }^{84}$ Once again, this is only an assertion without any evidence (or even argument) to suggest that it might be viable etymologically or historically. In fact, I know of no linguistic study 
independent of the Mon Paradigm that has been done on this topic to establish the theory as valid. Many of the terms for craftsmen and women start with the word pan, the root of which means "flower." A pan pai, for instance, is a blacksmith, while a pan pu is a carver in wood or stone, and a pan tan is a coppersmith. In all three cases, the particular craft is linked with the word for flower. Judson does not attribute pan to the Mon language, while Shorto has pankhi, "painter (in fresco)," dated at earliest to $1557 .{ }^{85}$ All this suggests to me that the Mon of Lower Burma borrowed these words that were crucial to the art and crafts of Pagán from that culture, rather than the other way around. Simply because a large number of Indian loanwords said to have been derived directly from Sanskrit rather than Pali (although no chronology is provided) were supposedly found in Mon, ${ }^{86}$ it was construed to imply that Burmese must therefore have obtained these words from the Mon, and not directly from the Sanskrit. Again, the assumption was that the Mon were early and the only intermediaries.

Yet centuries prior to Mon-Burman contact, there is evidence of written Sanskrit as well as Sanskrit Buddhism in Śrī Kṣetra and Pagán. And given the closeness of the Pyū and Burman language, culture, and history, there is no need to conclude that the Burmans obtained its Sanskrit words only via the Mon. ${ }^{87}$ These terms could have been derived from Tamil or Tibeto-Burman, and especially from the Pyū, a people well known for their skills in gold and silversmithing. ${ }^{88}$ The terms had probably become part of Burmese vocabulary centuries before the first Burman contact with the Mon.

Thus the etymology of Pagán's vocabulary of temple construction, comprising a whole compendium of words that are either references to or constitute different parts of temples and stupas and their accouterments came from Pyū, Old Burmese, Sanskrit, and Pali, but rarely, if ever, from Mon.

In short, the inclusion of a "Mon phase" in Luce's four-phase evolutionary sequence is entirely spurious, made to coincide with the "Mon period" of King Kyanzittha's reign, the topic of Chapter Ten. It has more to do with reinforcing the thesis of an early Mon contribution to Pagán civilization than with constructing a viable theory from actual evidence regarding the origins and development of the temple at Pagán.

\section{An Alternative Scheme}

Without the intellectual shackles of the Mon Paradigm, how might the evolution of the Pagán temple (and peripherally, the stupa) look? First, once the evolution of the solid stupa in Burma is assessed independently not only of the $g u$ but of a prior Lower Burma influence, the path becomes much clearer. Leaving aside for a moment those ruins at Beikthano the super- 
structure of which could well have been stupas, as some scholars contend, ${ }^{89}$ the more immediate prototypes of the Pagán stupa found within Burma itself seem to have been the Payagyi, Payamā, and Bawbawgyi temples of seventh-century Śrī Kṣetra (see Figure 5). In early Pagán, the style is reproduced by the Ngakywènadaung, the Būpaya, and the Lokananda, all of which are estimated to have been built prior to or during the eleventh century (see Figure 5). From another eleventh-century stupa, the Paunggu-paya of Myinkaba, several distinctly Pyū bronzes and stone sculptures have been excavated..$^{90}$ This establishes another fairly solid link between Pyū culture and early Pagán stupas. Even the Aśokan method of "repairing" solid stupas found in ancient India-encasing the old stupa with a new one-was used often in Pagán ${ }^{91}$ and is still used today, ${ }^{92}$ suggesting that some stupa repair traditions came early and directly from India.

The mid-eleventh-century Shwéhsandaw and the late eleventh-century Shwézigôn followed these earlier stupa styles, which were subsequently elaborated in the late twelfth-century Dhammayazika and culminated in the mid-thirteenth-century Hsutaungpyi Zedi ${ }^{93}$ and the late-thirteenth-century Mingalazedi. There are, of course, hundreds of other stupas of all sizes that are less well known, but which follow this path as well and can be found in Pichard's work. This essentially bell-shaped stupa is then elongated dramatically or subtly in the centuries that followed, finding brilliant expression in the mid-fifteenth-century Htupayôn of Sagaing, the Shwémawdaw of Pegu, and the Shwédagôn of Yangôn (see Figure 6); the epigraphic evidence for the latter two, notwithstanding their legends, does not precede the fifteenth century.

However, this path of development does not imply that no variations on the bell-shaped theme existed. Nor does it mean that one bell-shaped stupa necessarily produced another bell-shaped stupa that came later; the later stupa may have had its own immediate prototype. There is no reason to infer a linear, cause-and-effect relationship between earlier temples and later ones. Indeed, in some cases the bell shape reverted to the less elongated, pre-Śrī Kṣetra and pre-Pagán style of Śrī Lan̉ka's Anurādhapura. An example of this is the Kaungmhudaw of King Thalun, built in the seventeenth century (see Figure 8). Because the recreation of the purity of the past is central to the concept of religious reform in Theravāda Buddhism, one often finds ancient forms repeated or resurrected.

In contrast to the stupa, where the exterior shape is considered a major component of its style, it is the gu or hollow temple's internal structure that is more important, for that in large part determines form and shape, which in turn defines style. Analysis of its development is less an exterior visual assessment of changing or continuing shapes, and more an examination of changing or continuing internal structures. Of these the most important is 
the floor plan, the foundations upon which is built, in conjunction with vaulting principles, its total visual component.

And like the stupa, the prototype of the gu goes back to second-century BC Beikthano and its apparent contemporary, Binnaka, even to the extent to which the structure was apparently deliberately "misaligned." 94 In Beikthano we usually find the "one-face" design, which has an interior space that surrounds a solid central core that obviously supported a tower above it. ${ }^{95}$ Although its use at Beikthano as a religious structure cannot be confirmed until perhaps the fourth century AD, ${ }^{96}$ its design, especially the floor plans and superstructural support, clearly foreshadows the small one-face and "four-face" temples at Śrī Kṣetra. The basic difference among these early, small hollow temples, or between them and their larger, later counterparts at Pagán, is essentially one of variations on the same theme rather than something fundamentally new and different (see Figure 9).

At Śri Kșetra, another option was found for the central core: the vaulted chamber. This suggests that the principle of vaulting was still unknown at the earlier Pyū sites of Beikthano and Binnaka, but was known by the time of Śri Kṣetra, although that remains to be seen, for the presence of a solid core does not necessarily mean the absence of the vault. Both can be found coterminously with Śrī Kșetra's existence as a center of Pyū culture, whereas that cannot be proved to be the case earlier. To the

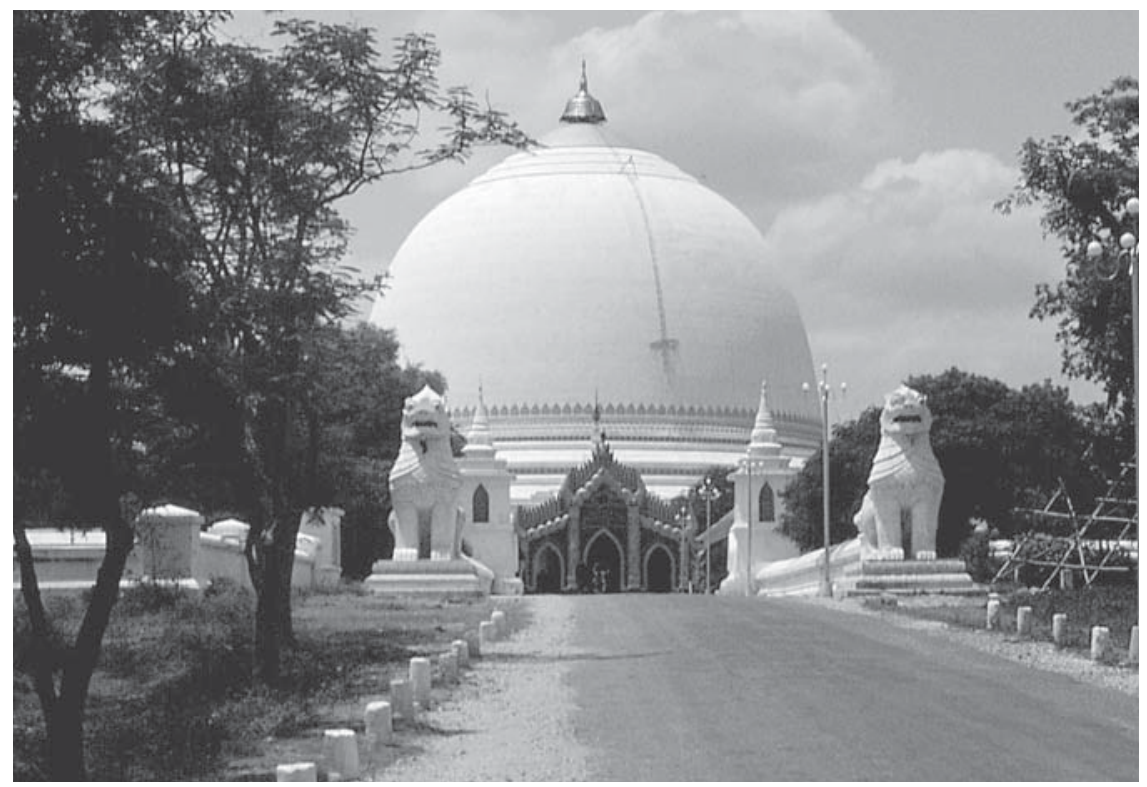

Figure 8: Devolution of the Burma stupa: The Kaungmhudaw 
basic one-face plan of Beikthano and Binnaka, one or more vestibules were sometimes added by the time of Śrī Kșetra. Their ground plans are asymmetrical, "looking" towards the single main entrance. As we can see in the "unnamed" temple in Figure 9, the single-entrance (one-face) temple had already developed a form - with a vestibule almost equal in size to the main chamber-that would be used in most single-face temples at Pagán. The best-known temples at Śrī Kṣetra in this one-face design are the Bèbè and the East Zegu, the style Luce had earlier labeled Mon.

By the seventh or eighth centuries, and the zenith of Pyū culture at Śī Kșetra, another design appears: the Léymyethna (literally "four-face") style, but with the solid, central core of Beikthano and Binnaka still intact (see Figure 10). As such, the Léymyethna design does not "favor" any particular direction (as its name- "four-face"-indicates) and may reflect the introduction of some new ideology or simply more confidence in the use of certain engineering techniques, or perhaps both.

These two basic $g u$ styles $^{97}$ of Śrī Kșetra and their variations and elaborations would, with very few exceptions, eventually dominate the $g u$ of Pagán. Most are either of the one-face, single-main-entrance, asymmetric, long-axis style, usually but not always facing east, or the four-face, fourentrance, equal-axis, symmetric style, approximately facing the cardinal directions. Most Pagán gu are the one-face temple style. Neither design has anything to do with ethnicity. (See Figures 11 and 12 for the chronological pattern of $g u$ built and for the percentages of the basic gu styles.).

At Pagán, one-face, single-entrance style temples found expression in the Nanpaya, Nagayôn, Thatbyinnyu, Sulamani, and Gawdawpalin. As Figure 9 demonstrates, the floor plans of the one-face temple remained essentially the same regardless of political chronology or size of the structure. Although one could argue that the larger temples actually had more than one doorway (which is true), they still possess only one main entrance towards which the central image and the ground plan are oriented. The other openings are quite obviously smaller and subordinate and have been added for light, balance, and other reasons; they are essentially elaborations on the overall one-entrance theme.

The prototype for the four-face plan, apparently appears first in the Léymyethna temple of Śrī Kṣetra. ${ }^{98}$ At Pagán, this design finds magnificent fruition in what is probably the eleventh-century Ânanda and its "Greek cross" floor plan, and the monumental and equally majestic mid-twelfthcentury Dhammayangyi. As with the single-entrance temples, there are dozens of smaller versions and variations on the four-face theme built later in the thirteenth century, as illustrated by the Léymyethna (at Wetkyi-in, temple no. 290 in Pichard). As Figure 10 shows, the floor plans of these four-face temples, like the one-face structures, continued to hold to that 


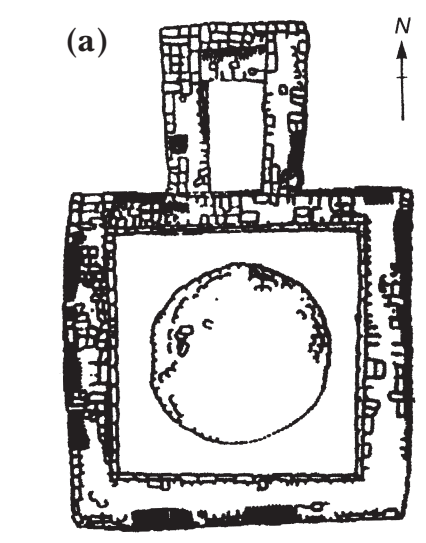

(b)
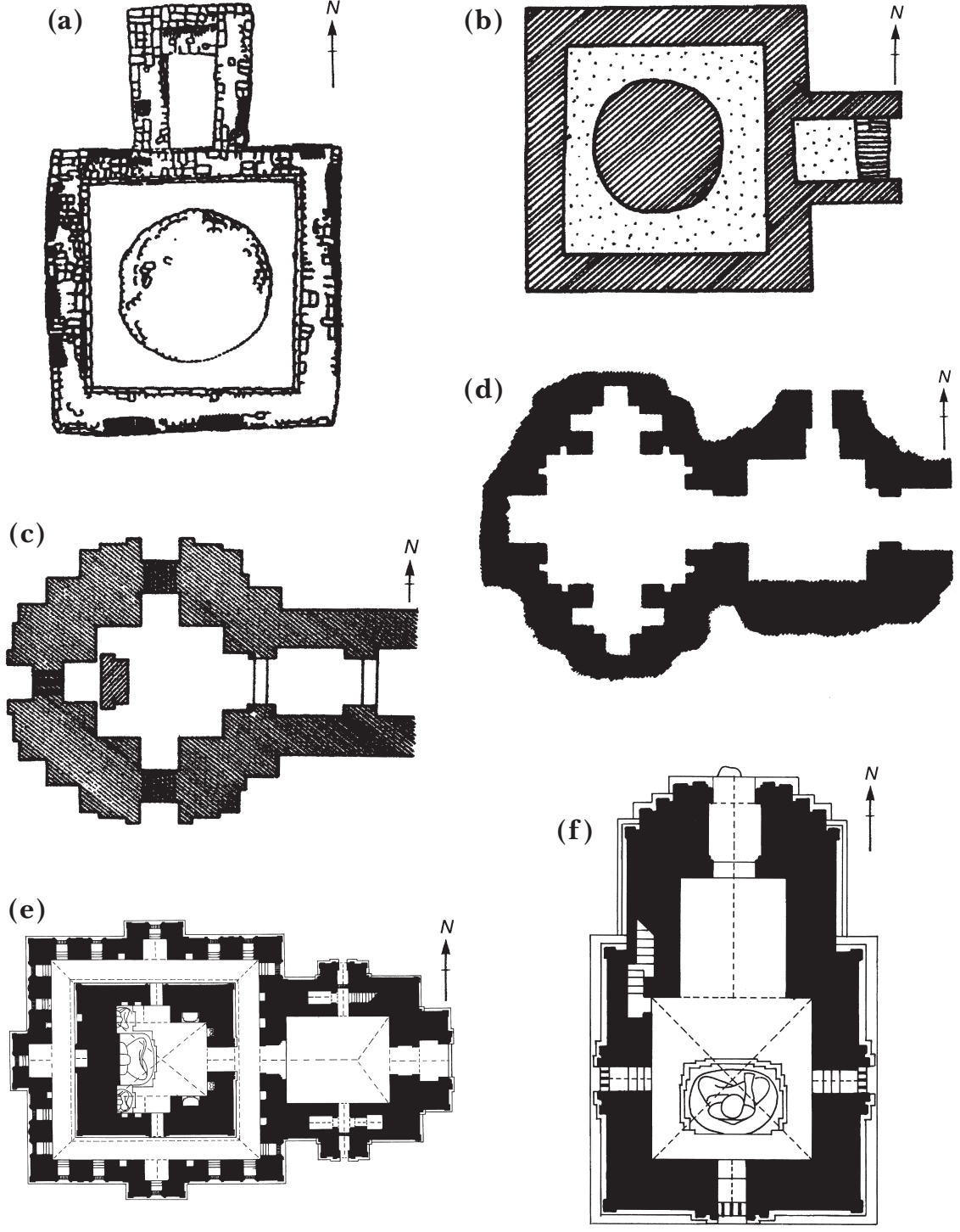

Figure 9: Ground Plans of "One-Face" Temples. Sources: G. H. Luce, Phases of Pre-Pagan Burma, Volume 2 (Oxford, 1985), and Pierre Pichard, Inventory of Monuments at Pagan (Mumbai, 1999). (a) Second-fourth-century Pyū structure at Beikthano; (b) Second-fourth-century Pyū structure at Binnaka; (c) East Zegu, seventh-century Pyū temple, Śrī Kṣetra; $(d)$ Unnamed, seventh-ninth-century (?) temple, Śrī Kṣetra; (e) Păhtothămyā, mid-tenth century (?); (f) Lokahteikpan, early eleventh century (?); (g) Nanpaya, eleventh century (?); (h) Nagayôn, late eleventh century (?); (i) Kubyaukgyi, early twelfth century (?); ( $j$ ) Shwégugyi, 1131 AD; ( $k$ ) Thatbyinnyu, twelfth century (?); (l) Sulamani, 1183 AD; (m) Shinmahti, thirteenth century (?); (n) Hpayathonzu, thirteenth century 
(g)

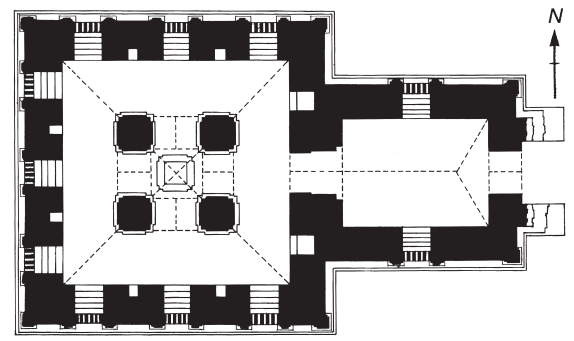

(i)

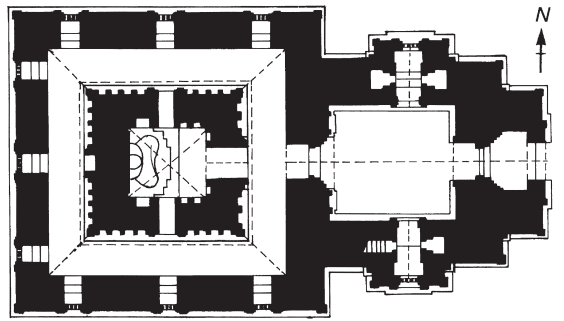

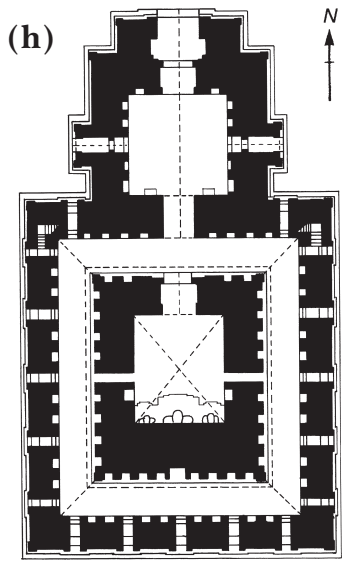

(k)

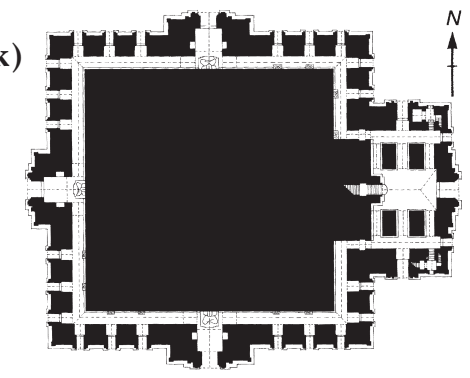

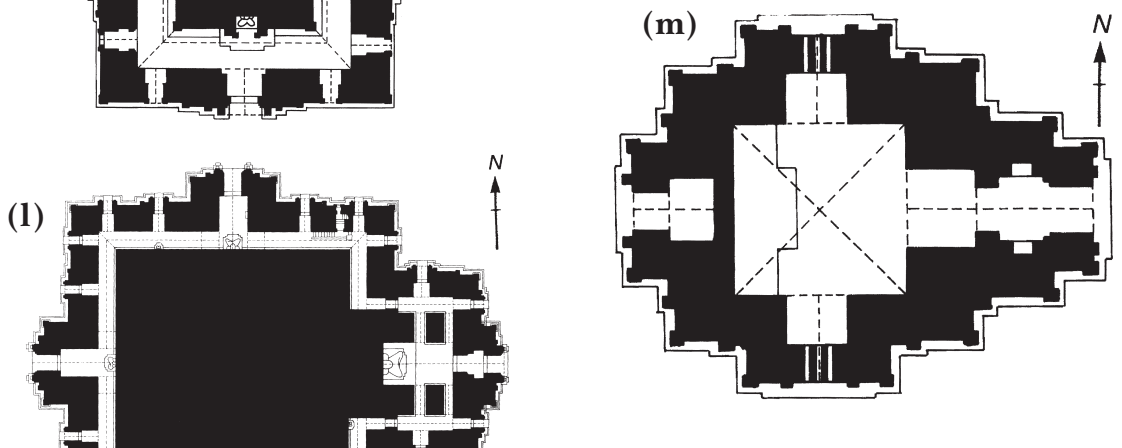

\section{1}

पnif

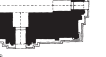

(n)

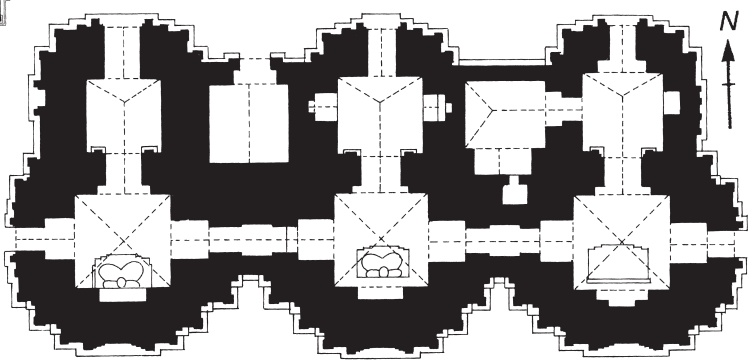



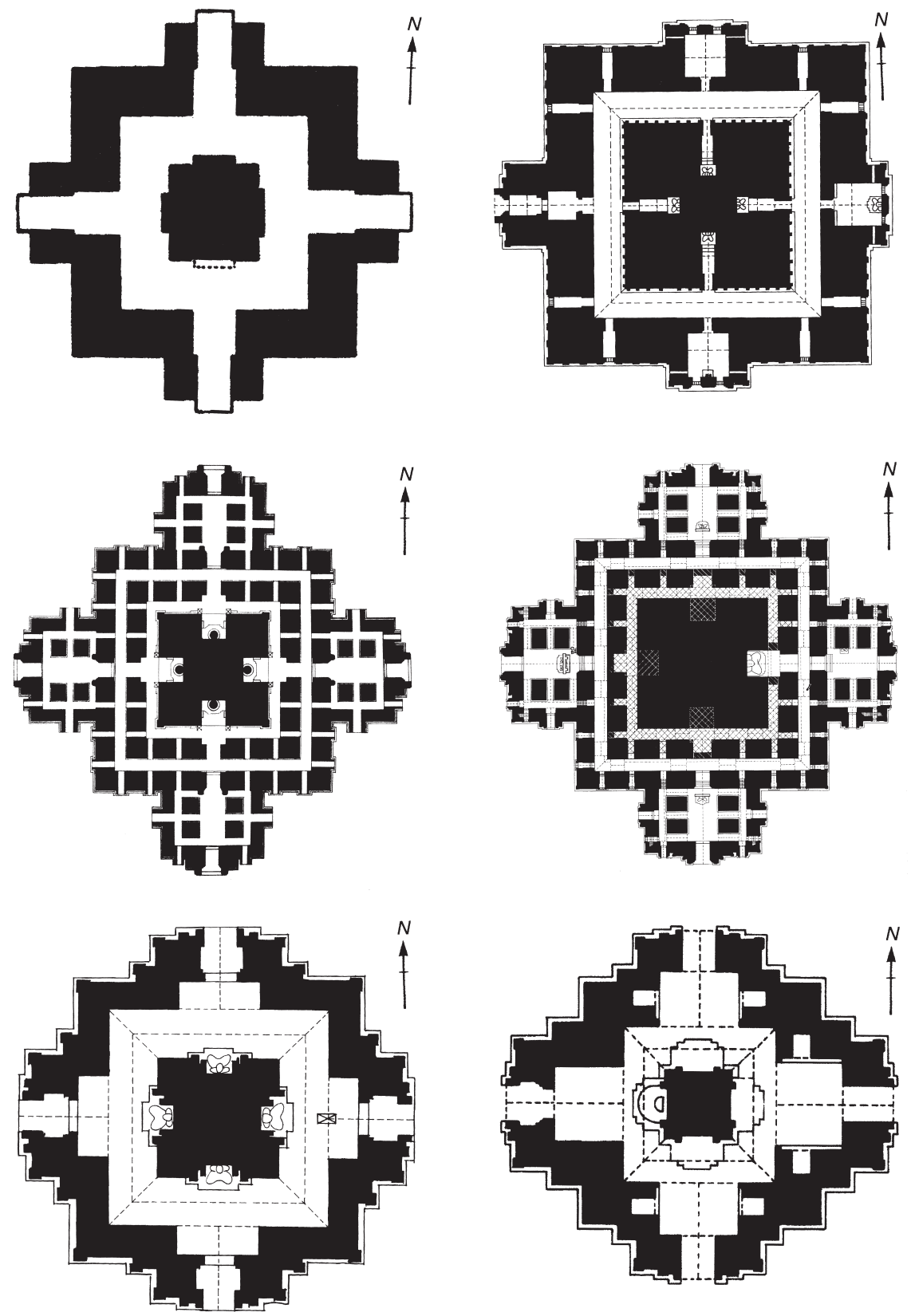

Figure 10: Ground Plans of "Four-Face" Temples. Sources: G. H. Luce, Phases of Pre-Pagan Burma, Volume 2 (Oxford, 1985), and Pierre Pichard, Inventory of Monuments at Pagan (Mumbai, 1999). Top left: Śrì Kṣetra Léymyethna, seventh century AD; Top right: Myinpyagu, eleventh century (?); Middle left: Ānanda, early twelfth century (?); Middle right: Dhammayangyi, 1165 AD; Bottom left: Kalakyaung, 1236 AD; Bottom right: Léymyethna, thirteenth century 


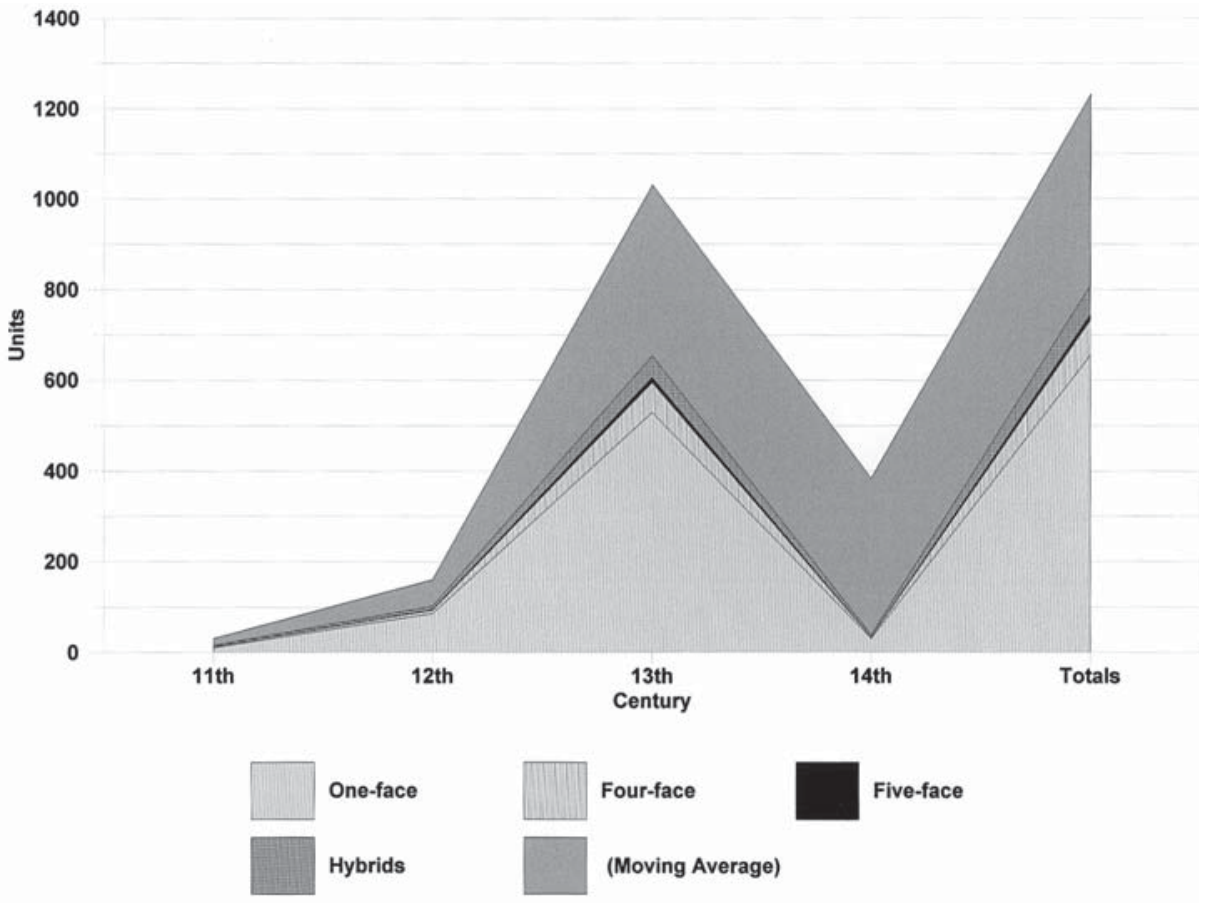

Figure 11: $G u$ Styles, Eleventh to Fourteenth Centuries
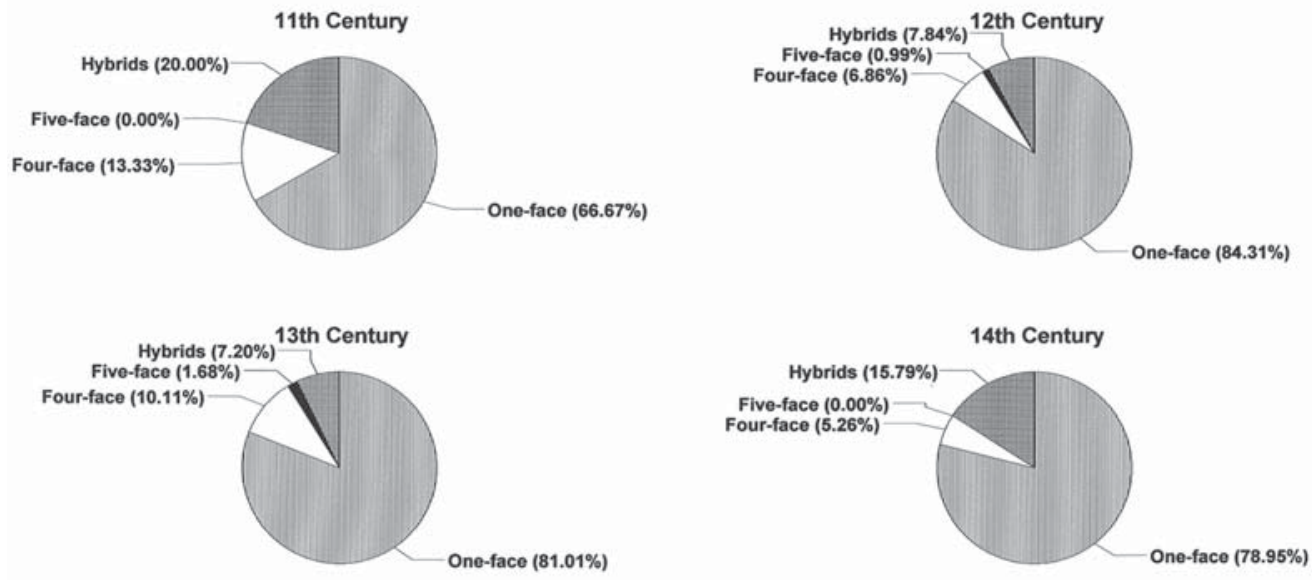

Figure 12: $G u$ Styles (Percentages), Eleventh to Fourteenth Centuries 
principle throughout the centuries regardless of political fortunes, ethnicity, or size of the building.

Of all the hollow temples built at Pagán between the eleventh and fourteenth centuries, over 80 percent are of the asymmetrical, one-face design, while the four-face variety, the next largest in number, comprise a little more than 13 percent of total production (see Figure 12). ${ }^{99}$ Most of the oneface temples were built in the twelfth century, which had clearly become the most popular design at the time-perhaps reflecting an appreciation of "classical" Pyū traditions.

Each of the two basic gu styles seems to have produced some hybrids that resulted in pentagonal and later, octagonal temples (as well as stupas). ${ }^{100}$ The pentagonal-literally "Ngamyethna" or "five-face"-temples are sometimes five one-face-style temples placed more or less back to back, as in the Ngamyethna, shown in Figure 13, or a variation of the four-face temple made to produce a pentagonal structure. ${ }^{101}$ In one case, the Hpayathonzu (literally, "group of three payas," here, temples), three one-face-style temples are strung side by side with connecting corridors (see Figure 9).

Often the one-face and four-face plans or their variations are combined so that, for instance, a temple is square and symmetrical but has only one main entrance and connected vestibule, with the central Buddha image facing that entrance. Or the temple is asymmetrical, but with four main entrances and four main Buddhas facing the four directions. Sometimes one of them comprises the first storey while the other becomes the second. Both the Minanthu Léymyethna and the Tonnekhya shown here in Figure 13 , are clearly combinations of the two styles, where the asymmetrical oneface design and the symmetrical four-face style have been fused.

To these two basic styles and their variations, stupa components were added, resulting in a combination of gu and stupa which may have been the reason Luce concluded that the temple evolved from the stupa. One of the best examples of this synthesis is the Myinpyagu, which looks like a solid stupa from the outside, but is in fact a symmetrical, four-face hollow temple inside. Similarly, the Dhammayazika, although a solid stupa, has five smaller gu symmetrically arranged on each face of the pentagon. (Both are shown in Figure 13.) There are a number of pentagonal monuments at Pagán, of which the Dhammayazika is the example par excellence. ${ }^{102}$ This pentagonal theme was extended to octagonal temples in later centuries, most built in the eighteenth and nineteenth. A very recent example is U Ne Win's Māhawizayā ("great victory") at the base of the Shwédagôn in Yangôn, which was built in the late 1970s or early 1980s.

In the same way that the solid stupa's exterior could be refined and embellished-for instance, the cetiya's anda might be bulbous or elongated - the gu's interior also provided countless architectural possibilities, espe- 

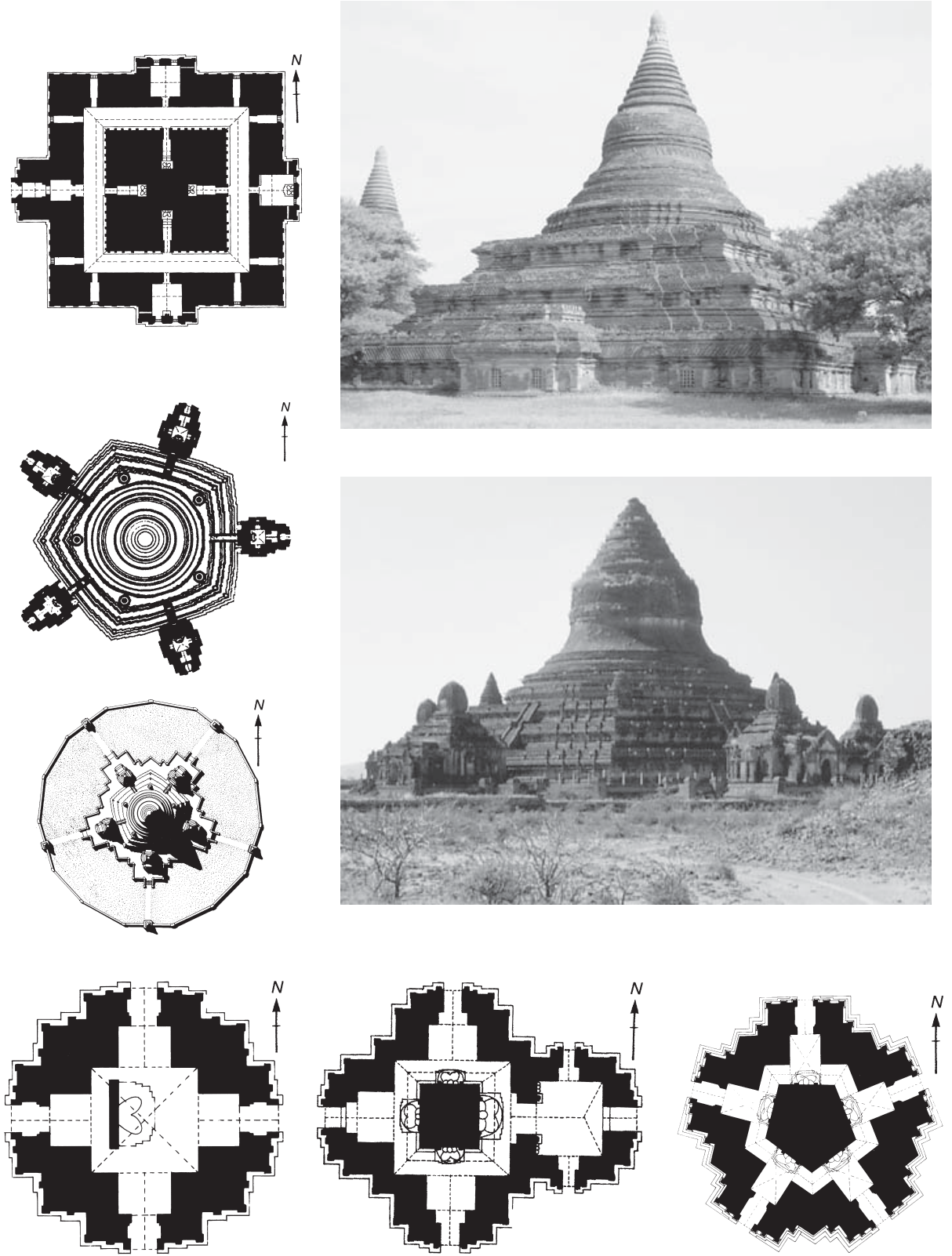

Figure 13: Ground Plans of Hybrids and Combinations. Source: Pierre Pichard, Inventory of Monuments at Pagan (Mumbai, 1999) and author's photographs. Top left: Myinpyagu, ground plan; Top right: Myinpyagu, exterior; Second left: Dhammayazika, exterior; Third left: Dhammayazika, aerial simulation; Middle right: Dhammayazika, with axial temples; Bottom left: Tonnekhya, thirteenth century, combination of one-face and four-face styles; Bottom center: Minanthu Léymyethna, thirteenth century, combination of one-face and four-face styles; Bottom right: Ngamyethna Hpaya, thirteenth century, combination of five one-face temples 
cially with the use of true arches. There might be minor entrances on the sides of one-face, single-entrance temples, or vestibules added, or additional storeys built which would then need additional images and structural support such as hidden, relieving arches, corridors, and stairways, much of which did not necessarily affect the outside shape of the temple in any obvious way. ${ }^{103}$ Thus although visually it may appear as if there were a very large variety of gu designs at Pagán, when the cross sections and particularly the ground plans are scrutinized, it is quite obvious that virtually all of them are variations on the one- or four-face theme, prototypes first found at Śrī Kșetra, to which were added certain components of the solid cetiya. The rest, with very few exceptions, are sometimes simple, other times elaborate, syntheses of those two basic plans.

When we view the development of religious edifices in this way, as a parallel development of the stupa and temple with some crossing over, and when we base our analysis on architectural criteria, the Mon Paradigm becomes totally extraneous. Introverted Mons and extraverted Burmans, heavy rainfall, a conquering trope, the romanticized personalities of the kings in whose reign the temples were built, and so on are no longer needed. The chronology of temples can now be determined according to the available evidence or left undated, while style can be assessed by simply following the structural and technological development of the edifices themselves.

Nor do we need to assume that "prototypes" must change into or produce a new "species" in order to satisfy a fetish about linear change and "progress," although that can and does happen. With regard to temples in Burma, prototypes often continue unchanged over the centuries in their prototype form, alongside whatever "new species" they might have also spawned. Late thirteenth-century Pagán temples retained their basic seventh-century Śri Kṣetra one-face design, an obvious continuity that does not, however, necessarily deny that processes of change were also taking place, producing branches and offshoots. This continuity of prototypes explains why stupas, such as the Shwézedi of the thirteenth century, ${ }^{104}$ is nearly identical in shape to the Shwéhsandaw (see Figure 6), thought to have been built nearly two hundred years earlier, or to the Myazedi, which is assigned to the early twelfth century. ${ }^{105}$

There is also no longer any need to force the chronology of the Păhtothămyā temple into a predetermined period of time in order to accommodate Aniruddha's alleged conquest of Thatôn and his bringing back certain texts in order to explain the presence of the textual themes painted in that temple. It means we can once again consider the viability of Burmese tradition regarding that temple, namely, that Saw Rahan, Aniruddha's grandfather was the one who built it in the mid-tenth century. ${ }^{106}$ With 
recent radiocarbon dating of Pagán's foundations relatively close to his reign, that tradition once more becomes perfectly feasible. Similarly, there is no longer any reason to assign the Lokahteikpan to a period contemporary to or later than the Myazedi Inscriptions in order to accommodate the Mon Paradigm thesis that written Mon preceded written Burmese. Its chronology can be decided by style as well as the presence in it of very early Old Burmese ink inscriptions, the paleography of which best places it with Aniruddha's votive tablets, preceding King Kyanzittha's Old Mon inscriptions. In short, we can now examine style with art historical evidence, rather than forcing it into a preconceived thesis.

\section{Conclusion}

It is true that art historians studying Pagán in recent years have been regularly interpreting "outside" the context of the Mon Paradigm, but so far not one has explicitly and directly challenged it. Now that the Mon Paradigm is no longer viable, however, data on the art and architecture of Pagán can be interpreted even more freely, and will not have to address spurious issues that have linked ethnicity to temple style, and temple style to undated interior murals and ink inscriptions. Art historians can also disregard the conventional and conjectural dating schemes assigned to many Pagán temples that have for so long followed the Mon Paradigm's assumptions. And as several scholars of Southeast Asian and Pagán art have been doing, ${ }^{107}$ more should now be inclined to acknowledge that influences from eastern or southern India or Śrì Lanka came directly to Pagán without first going through a Lower Burma Mon "transitional phase."

Students of Pagán art may find that a great deal more is owed the Pyu and direct Indic influences than has been realized or admitted heretofore -in part, a reaction to the "Indianization" theory of George Coedes made earlier-and that Upper Burma's, especially Pagán's temple architecture, probably owed nothing to Lower Burma. This is particularly true of the bell-shaped stupas of Yangôn and Pegu that stand out as exemplary models: they owed their symbolism, their form and design, their building techniques, and even their materials to early Pyū and Pagán stupas. Their evolution probably began with the Bawbawgyi, Payamā, and Payagyi of Śrī Kṣetra; developed into the Būpaya, Ngakywènadaung, and Lokananda of the early Pagán period; crystallized in the Shwéhsandaw and Shwézigôn of the eleventh, the Dhammayazika of the twelfth, and the Mingalazedi of the thirteenth centuries; continued in the mid-fifteenth-century Htupayôn of Sagaing, eventually to flower in the Shwédagôn of Yangôn and the Shwémawdaw of Pegu of the late fifteenth century (see Figure 6).

As for the hollow temple, no genuine Pagán-style gu of similar size and 
structure, with its most important, unique, and invariable feature-the pointed, radiating arch and its vaults- has yet been found thereafter anywhere in Burma. ${ }^{108}$ It appears that knowledge of the true arch may have been lost in Burma shortly after the Pagán Dynasty ended in the first half of the fourteenth century. Indeed, the vaulting of several small temples at Pinya, an early fourteenth-century city that briefly replaced Pagán as Upper Burma's center, shows clear signs of weak and crumbling arches, crudely buttressed by techniques we never see at Pagán, even as repair work (see Figure 14). Indeed, unrepaired arches at Pagán that were built centuries before the rise of Pinya still remain in much better condition than those built or repaired at later Pinya. ${ }^{109}$

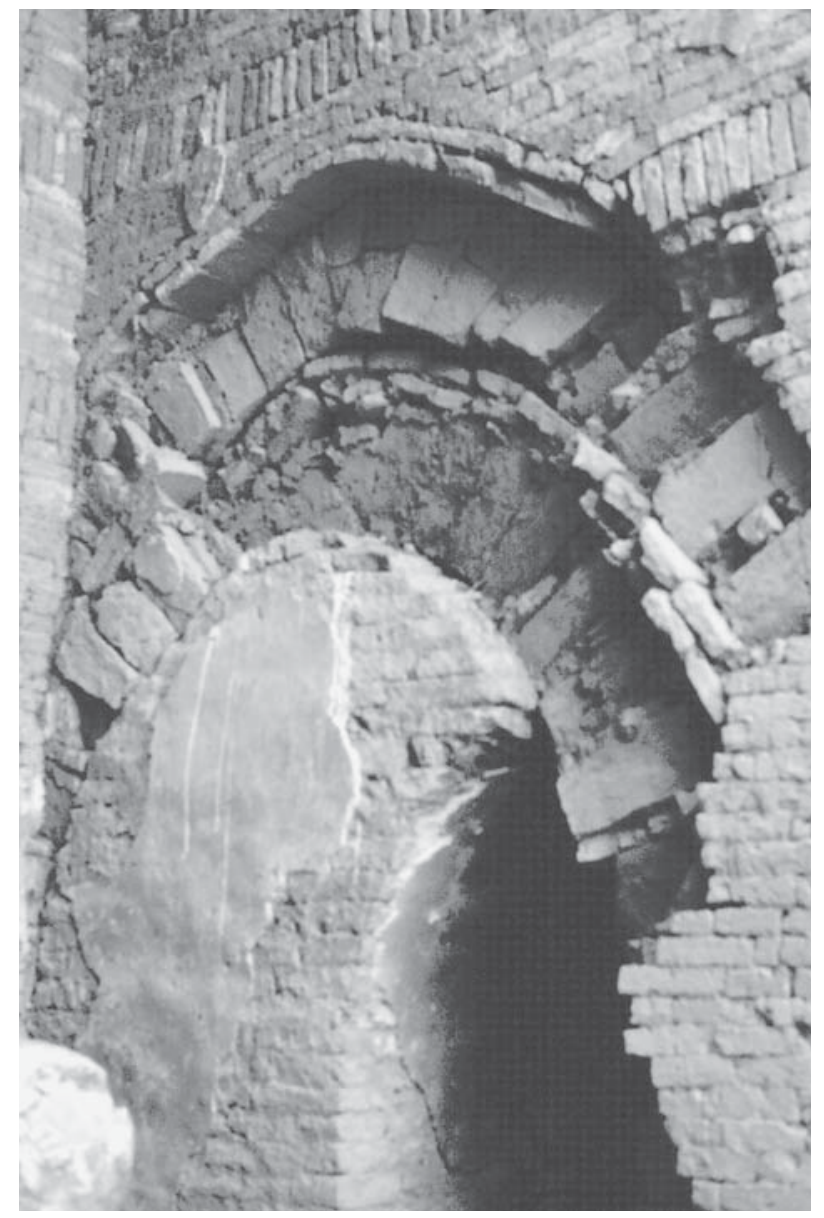

Figure 14: Pinya Arch 
Smaller hollow temples did continue to be built right up to the present, but none of these are even close in size or structure to the larger gu of Pagán such as the Ānanda, Sulamani, Dhammayangyi, and Htilominlo, which required true arch and vaulting principles to sustain their weight and size. In the late eighteenth century, when King Bodawpaya attempted to build the Mingun Pagoda-a structure he likely imagined to have been a Pagán-type Léymyethna-style gu - it was in fact a solid temple with no real interior, only small, token vestibules at each cardinal direction with crude, corbeled arches. The craftsmen and masons of the eighteenth century had clearly lost the knowledge of vaulting and keystone arching and could not reproduce the interior space so beautifully created by the magnificent vaulting at Pagán.

That loss had a direct effect on the style of future royal monuments, for they were all solid stupas. Of these, the Shwédagôn of the Lower Burma Pegu Dynasty has become the exemplary model until today, so that in Burma the evolution of the temple did not begin with the solid stupa but ends with it. In much the same way that, and as part of the general historical processes in which peoples and cultures, languages and script, urbanism and state formation, religion and conceptual systems moved-from north to south, from Upper to Lower Burma rather than the other way around-so did art and architecture. 